\title{
Spatial Variability of Microbial Communities and Salt Distributions Across a Latitudinal Aridity Gradient in the Atacama Desert
}

\author{
Jianxun Shen ${ }^{1}$ (D) Adam J. Wyness ${ }^{2,3} \cdot$ Mark W. Claire $^{1} \cdot$ Aubrey L. Zerkle ${ }^{1}$ \\ Received: 13 October 2020 / Accepted: 21 December 2020 / Published online: 13 January 2021 \\ (C) The Author(s) 2021
}

\begin{abstract}
Over the past 150 million years, the Chilean Atacama Desert has been transformed into one of the most inhospitable landscapes by geophysical changes, which makes it an ideal Mars analog that has been explored for decades. However, a heavy rainfall that occurred in the Atacama in 2017 provides a unique opportunity to study the response of resident extremophiles to rapid environmental change associated with excessive water and salt shock. Here we combine mineral/salt composition measurements, amendment cell culture experiments, and next-generation sequencing analyses to study the variations in salts and microbial communities along a latitudinal aridity gradient of the Atacama Desert. In addition, we examine the reshuffling of Atacama microbiomes after the rainfall event. Analysis of microbial community composition revealed that soils within the southern arid desert were consistently dominated by Actinobacteria, Chloroflexi, Proteobacteria, Firmicutes, Bacteroidetes, Gemmatimonadetes, Planctomycetes, and Acidobacteria, and Verrucomicrobia. Intriguingly, the hyperarid microbial consortia exhibited a similar pattern to the more southern desert. Salts at the shallow subsurface were dissolved and leached down to a deeper layer, challenging indigenous microorganisms with the increasing osmotic stress. Microbial viability was found to change with aridity and rainfall events. This study sheds light on the structure of xerotolerant, halotolerant, and radioresistant microbiomes from the hyperarid northern desert to the less arid southern transition region, as well as their response to changes in water availability.
\end{abstract}

Keywords Atacama microbiome $\cdot$ Function prediction $\cdot$ Extremophiles $\cdot$ Osmotic stress $\cdot$ Salt amendments

\section{Introduction}

The Atacama Desert in northern Chile is the driest non-polar terrestrial desert on Earth, spanning more than $1000 \mathrm{~km}$ in length from central Chile to southern Peru [1]. It is widely accepted as a Mars analog system based on its similar geomorphic landscape to Mars and multiple physicochemical aspects such as its hyperaridity, absence of water weathering,

Jianxun Shen

js365@st-andrews.ac.uk

1 School of Earth and Environmental Sciences and Centre for Exoplanet Science, University of St Andrews, St Andrews KY16 9AL, UK

2 Sediment Ecology Research Group, Scottish Oceans Institute, School of Biology, University of St Andrews, St Andrews KY16 8LB, UK

3 Coastal Research Group, Department of Zoology and Entomology, Rhodes University, Grahamstown 6139, South Africa high ultraviolet (UV) radiation, low levels of organic carbon, and large reservoirs of oxidants [2]. The microbial life is unique from other terrestrial locations because these organisms have been exposed to extreme conditions since the Late Jurassic 150 million years ago [1]. Thus, the environmental gradients within the Atacama Desert serve as an excellent model to investigate the influence of long-term aridity and different frequencies of precipitation-led water stress on soil microbial communities.

The newly available Atacama Database of microbiology [3] records 2302 microorganisms in the Atacama Desert, with reference to 633 previously published papers between 1966 and 2016. Among these microorganisms, 1741 species are from the Domain Bacteria. However, bacteria from unknown phyla still comprise $40 \%$ of the currently recorded Atacama microbiome [3]. These microbes are distributed throughout the soil profile, with surface inhabitants are generally more tolerant to strong UV radiation, and those found deeper in soils are more tolerant to hypersaline conditions [4]. Despite the extreme aridity, desiccation may not be the sole or even the 
primary factor influencing microbial life in desert environments, and highly saline and oxidizing soils can also be crucial factors.

Counter-intuitively, an abrupt increase in water availability in hyperarid soils is extremely harmful to xerotolerant microorganisms because these cells are induced to transform from the defensive or dormant state to the metabolically active state while unexpectedly being exposed to attack from extreme temperature and UV radiation [5]. In addition, excessive water causes high osmotic shock to the microbial semipermeable membrane and disturbs their survival strategies adapted for limited moisture [6,7]. After the heavy rainfall event in 2017 at the core region of the Atacama Desert, $75-87 \%$ of pre-rainfall species were undetectable, and no viable archaea or eukaryotes were detected in undrained brines [6]. Although these rainfall events can severely damage the extremotolerant microbial communities, previous studies demonstrated that the community structure can recover after 1 month in the central Namib Desert [8], or for more than 1 year at Salar Grande in the northern Atacama Desert [9], using a variety of biochemical mechanisms and osmoregulatory systems. Immediately after rainfall, microorganisms start producing proteins and metabolites that are crucial in fundamental biosynthetic pathways, energy supplements, desiccation resistance, radiation protection, and oxidation defense for the preparation of the upcoming hyperarid period [10].

Martian surface is likely to have been much wetter around $3-4$ billion years ago $[11,12]$ supported by the evidence of carved outflow channels, valleys, evaporitic basins, and northern paleoceanographic landforms [13-15]. Due to the biochemical importance of water, potentially extant microorganisms may have been thrived on early Mars. Between then and the drier planet we recognize today, a transitional dry period with occasional moisture has occurred [16]. On the more recent dry Mars, the soil $\mathrm{pH}$ is slightly alkaline (7.7-8.3) as determined by the Phoenix rover [17], which is similar to the $\mathrm{pH}$ 6.6-9.2 of Atacama soils [18-21]. Another similarity between Martian and Atacama soils is the nearly equivalent concentrations of highly soluble perchlorate $(0.4-0.6 \%$ for Mars [22] and 0.5-0.6\% for Atacama [23]) and total nitrogen (0.007-0.11\% for Mars [24] and $0.01-0.15 \%$ for Atacama [25]). Although precipitation is absent on the modern Mars, a radar analysis validates the existence of liquid water trapped by polar ice [26], and detection results by the Curiosity rover show evidence of temporary subsurface liquid during nighttime on equatorial Mars and possibly beyond [27]. Therefore, the rare heavy rain in the hyperarid Atacama acts as an analog to the transient availability of liquid water on Mars. Abundant hygroscopic chloride minerals and hydrated sulfate minerals were detected in the Phoenix and Curiosity exploration locations [28-30].

This study investigated the differences in microbiome and soil salt compositions along a latitudinal precipitation gradient of the Atacama Desert after the heavy rainfall event. Based on the soil relative humidity, Azua-Bustos et al. (2015) argued that María Elena South (MES) was drier than the commonly known hyperarid Yungay region [31], but no next-generation sequencing has been conducted to examine the MES microbial community. The primary research goals of this study are to explore the microbial community structure and functions in MES and their changes toward the more humid sites, to compare with some previous pre-rainfall Atacama Desert studies, and to investigate how water and salt amendments affect microbial growth in Atacama soils. Since the sampling was conducted half a year after the most recent massive rainfall, the recovery of microbial communities in the hyperarid core area was hypothesized to be in some middle point between the prerainfall condition and the more humid condition. The hyperarid sites that received more precipitation were hypothesized to be decimated more seriously and thus might have lower biomass. As high salinity results in hyperosmotic pressure, excessive salt amendments were hypothesized to decrease the microbial abundance. Considering the hygroscopic property of some abundant Atacama minerals such as halite $(\mathrm{NaCl})$ and gypsum $\left(\mathrm{CaSO}_{4} \cdot 2 \mathrm{H}_{2} \mathrm{O}\right)$, previous researchers argued that these minerals could be ideal microhabitats for endolithic microorganisms within arid environments due to the moisture support [32-35]. According to a water-stable isotope study [36], the crystallization water of gypsum could supply > $70 \%$ water source to even higher plants. Despite the hypersaline condition, chloride and sulfate were hypothesized to benefit the microbial survival and growth to some extent. To live under long-term arid conditions and tackle the rewetting after rainfall, microorganisms hypothetically possessed pathways to resist osmotic stress, ionizing radiation, extreme dryness, and to utilize limited nutrients. Marker gene metabolic inference analysis was performed to preliminarily examine this postulation.

\section{Methods}

\section{Site descriptions and soil characterizations}

Samples were collected from the Atacama Desert, northern Chile, on November 30-December 6, 2017, after an unprecedented heavy rainfall event that expanded from the Yungay region during June 6-7 in 2017 [6] with $19.6 \mathrm{~mm}$ of rainfall, according to the record at Antofagasta Rain Gauge (23.5975 $\mathrm{S}, 70.3867^{\circ} \mathrm{W}$, altitude: $50 \mathrm{~m}$ ). The rainfall at each sampled site, for June 2017, was listed in Table S1. Soils were collected from seven field sites along a $\sim 800 \mathrm{~km}$ north to south latitudinal transect from $22^{\circ} \mathrm{S}$ to $29^{\circ} \mathrm{S}$ (Fig. 1a and Table S1) as described by Shen et al. (2019). Briefly, samples were obtained from three hyperarid sites (María Elena South (MES), Point of No Return (PONR), and Yungay) and four-transition zone 


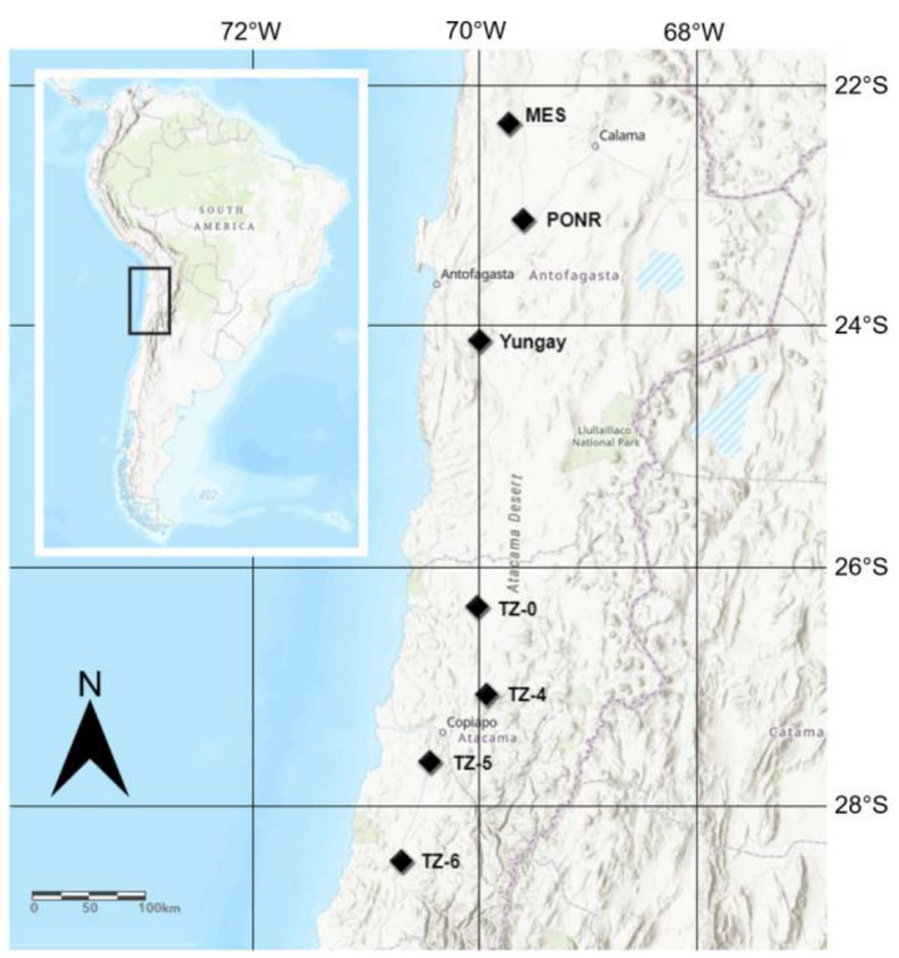

(a)

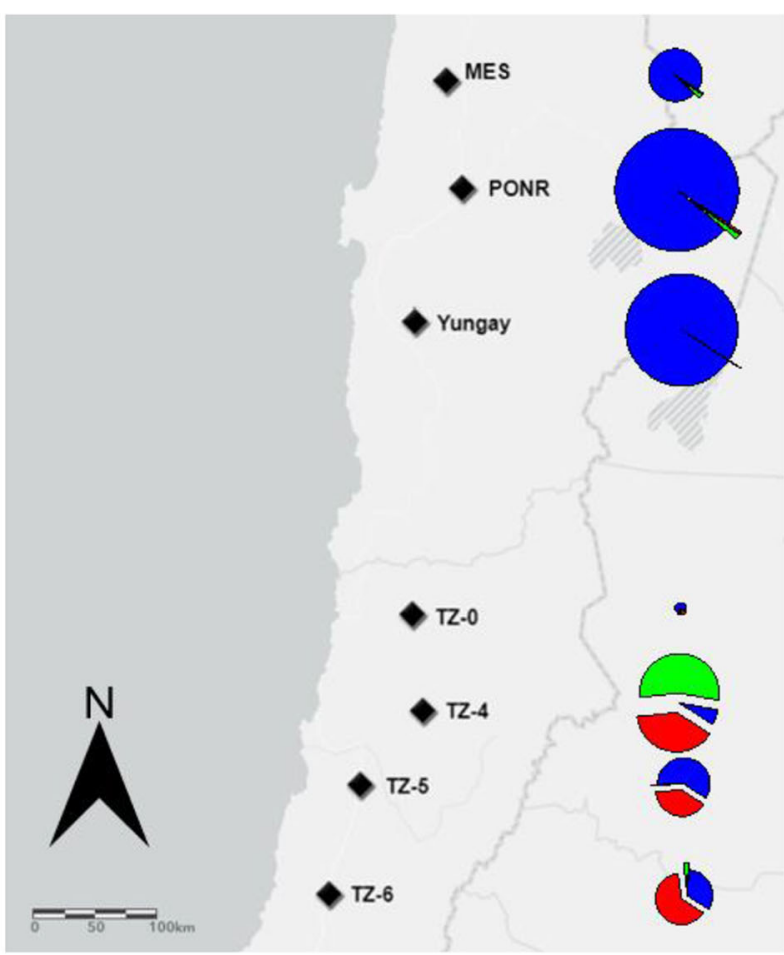

(b)

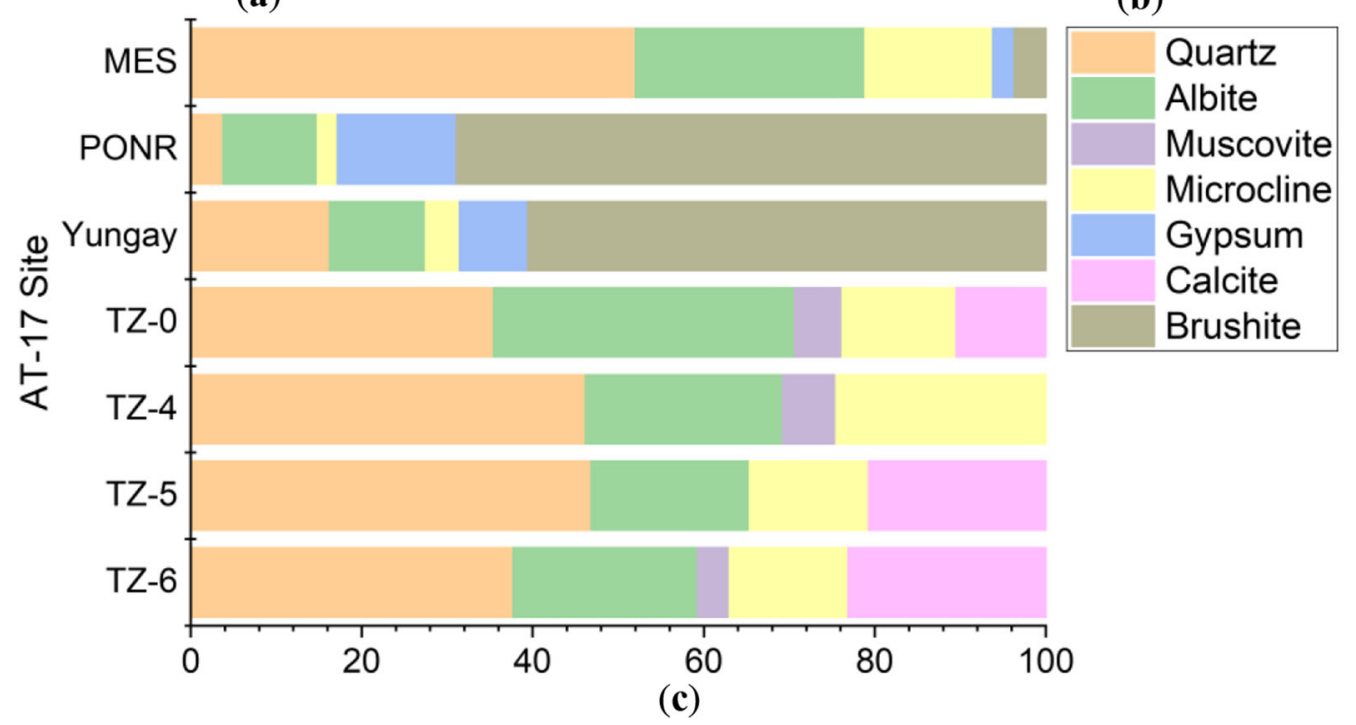

Fig. 1 a Geographic locations of the Atacama Desert AT-17 sampling sites, including María Elena South (MES), PONR (Point of No Return), Yungay, transition zone 0 (TZ-0), TZ-4, TZ-5, and TZ-6. b Soil collection sites in the Atacama Desert, illustrating the major salt distribution of different sites. The size of the pie charts represents the concentrations of soluble salts $\left(\mathrm{Cl}^{-}\right.$, red; $\mathrm{NO}_{3}{ }^{-}$, green; $\mathrm{SO}_{4}{ }^{2-}$, blue). The areas of pie charts range from 30 to $17,000 \mathrm{ppm}$. $\mathbf{c}$ Percentages of different minerals in AT17 samples determined by X-ray diffraction (XRD) sites (TZ-0, TZ-4, TZ-5, and TZ-6). Visible vegetation cover (sparse dried grasses and shrubs) appeared in regions close to the sampling sites of TZ-4, TZ-5, and TZ-6. Within each site, three random pits were sampled at a depth of $10-20 \mathrm{~cm}$ for geochemical analyses and DNA extractions, and the third sampling pit was additionally sampled for microbial cell counting and cultivations. All samples were collected with a sterile sampling trowel, placed into sterile Whirl-Pak® bags
(Nasco, Fort Atkinson, USA). Soils obtained in 2017 were collectively referred to as AT-17.

General soil properties $(\mathrm{pH}$, electrical conductivity, major sediment elements by X-ray fluorescence (XRF) methods, and the concentrations of total organic carbon (TOC), total organic nitrogen (TON), carbonate, and nitrate) of AT-17 geochemical samples were reported in Shen et al. (2019). AT-17 geochemical samples were sieved through a 1.4-mm sieve prior to 
ion chromatography for soluble anion determinations as described in Shen et al. (2019).

Additionally, AT-17 soil samples for X-ray diffraction (XRD) were crushed using a Planetary Micro Mill (PULVERISETTE 6, FRITSCH) and sieved through a $355-\mu \mathrm{m}$ sieve. The mineralogy of these crushed and sieved samples was analyzed on a Philips X-Ray Diffractometer (PW1830 generator, PW1050/80 goniometer, $\mathrm{PW} 1710$ diffractometer) using Co K $\alpha$ radiation. Generator settings for the measurement were $30 \mathrm{kV}, 30 \mathrm{~mA}, 3-70^{\circ}$ range $2 \theta$ scan, $0.01^{\circ}$ step, and $1 \mathrm{~s} / \mathrm{step}$. Mineral phases were identified using the EVA 2 software from SOCABIM with the ICDD PDF2 database.

\section{DNA extractions and sequencing}

Due to the low biomass in Atacama soils, AT-17 microbiological samples for DNA extraction were well sealed and stored under dry conditions (30-70\% relative humidity) for 1 year at $4{ }^{\circ} \mathrm{C}$ prior to finding a suitable cell lysis device, the Precellys 24 tissue homogenizer. The daily atmospheric relative humidity of the Atacama Desert ranges from $0 \%$ at noon to $100 \%$ at midnight in the hyperarid core area, with a mean value of $\sim 30 \%$ [31, 37, 38]. Since warmer air has a higher capacity for moisture, the moisture content at $4{ }^{\circ} \mathrm{C}$ is generally similar to that of the air above Atacama soils. The annual temperature of the Atacama Desert was between $-5{ }^{\circ} \mathrm{C}$ and $40{ }^{\circ} \mathrm{C}[25,39]$, so we attempted to store soils at a low but comparable temperature to keep microbial communities alive but as dormant as possible. Due to the extreme aridness of these dry sandy soil samples, the effect of the storage duration should be insignificant, as even biolipids could preserve for more than one billion years [40]. DNA of AT-17 soils from three pits of each site were extracted together with an extraction blank using the MP Biomedicals ${ }^{\mathrm{TM}}$ FastDNA ${ }^{\mathrm{TM}}$ SPIN Kit for Soil following a modified manufacturer's protocol: during the cell lysis step, mixtures were incubated at room temperature for $1 \mathrm{~h}$. DNA extracts were amplified in triplicate for barcoded Illumina 16S metagenomic sequencing using KAPA HiFi HotStart ReadyMix (KAPA Biosystems, Roche, UK) and 16S rRNA primer pair 341F, 5'-CCTA CGGGNGGCWGCAG-3', and 785R, 5'-GACT ACHVGGGTATCTAATCC-3' using the Nextera index kit (Illumina $\left.{ }^{\circledR}\right)$. Amplicons were quantified using an Invitrogen ${ }^{\mathrm{TM}}$ Qubit $^{\mathrm{TM}} 3.0$ Fluorometer, and only samples with more than about $0.5 \mathrm{ng} / \mu \mathrm{L}$ yields (i.e., 3 pits in MES, 2 pits in TZ-0, 3 pits in TZ-4, 3 pits in TZ-5, and 3 pits in TZ-6) were passed for following preparation of sequencing. Triplicate amplicons from each pit were pooled together and concentrated by heating at $50{ }^{\circ} \mathrm{C}$ to a final volume of $50 \mu \mathrm{l} .16 \mathrm{~S}$ rRNA amplicons for Illumina MiSeq System was replicated and sequenced by following 16 S Metagenomic Sequencing Library Preparation together with a 20\% PhiX control and the extraction blank using paired-end 300-bp reads with v3 Chemistry, modified by extending the amplicon PCR reactions from 25 to 29 cycles due to low product yield.

\section{Assessments of bacterial abundance and viability}

The abundance and viability (proportion of viable cells in total cells) of AT-17 microbial communities were analyzed via duplicate trypan blue staining assay within 1 month of sample collection and cultivation methods within 1 month and replicate within half a year after sample collection. Duplicate AT17 microbiological soils from the third sampling pit of each site were suspended and $10 \times$ serially diluted two to four times to clear out any sand particles. $0.4 \%$ Trypan blue was added to $9 \times$ of the dilute solution. Viable (non-colored) and non-viable (blue) microbial cells were mounted on a Hirschmann Instruments ${ }^{\mathrm{TM}}$ Counting Chamber and counted using oil immersion light microscopy (AmScope).

Duplicate AT-17 samples from the third sampling pit of each site were suspended and homogenized in 1:1 volume $(\mathrm{mL})$ :weight $(\mathrm{g})$ of sterilized ultrapure water for microbial cultivations. Different nutrient effects from various cell culture plates on the colony growth of culturable heterotrophic microbes were considered, so four types of agar plates were selected in this culturing experiment: (1) ultrapure agarose plate ( $15 \mathrm{~g} / \mathrm{L}$ agarose), with agarose as the sole nutrient source; (2) tryptic soy agar plate $(15 \mathrm{~g} / \mathrm{L}$ agar, $15 \mathrm{~g} / \mathrm{L}$ peptone, $5 \mathrm{~g} / \mathrm{L}$ soyabean digest, $0.7 \mathrm{~g} / \mathrm{L}$ lecithin, $5 \mathrm{~g} / \mathrm{L}$ Tween 80), with casein and plant-derived organics and glycerophospholipids as additional nutrients; (3) Luria-Bertani (LB) agar plate $(15 \mathrm{~g} / \mathrm{L}$ agar, $10 \mathrm{~g} / \mathrm{L}$ tryptone, $5 \mathrm{~g} / \mathrm{L}$ yeast extract, $5 \mathrm{~g} / \mathrm{L} \mathrm{NaCl}$ ), with casein and yeast-derived organics and table salt as additional nutrients; and (4) plate count agar $(9 \mathrm{~g} / \mathrm{L}$ agar, $5 \mathrm{~g} / \mathrm{L}$ tryptone, $2.5 \mathrm{~g} / \mathrm{L}$ yeast extract, $1 \mathrm{~g} / \mathrm{L}$ dextrose), with casein and yeast-derived organics and glucose as additional nutrients. Based on some preliminary tests for countable colony number estimations, an appropriate amount of soil suspension was spread on these four types of culture medium. Visible colonies were counted after 20 days of incubation at $21{ }^{\circ} \mathrm{C}$. Without additional amendments, these sets were also the controls for colony number normalizations described in Table 1.

\section{Salt and water amendments}

To inspect the effects of a variety of excessive dissolved salts on the viable microbial community, soils from the third sampling pit of each site were amended with $4.5 \mathrm{~mL}$ salt solutions. Solutions of $10 \%$ sodium chloride, $10 \%$ sodium sulfate, $10 \%$ sodium carbonate, $10 \%$ sodium acetate, and $10 \%$ sodium L-lactate were prepared in ultrapure water and autoclaved at $121{ }^{\circ} \mathrm{C}$ for $30 \mathrm{~min}$. After cooling to room temperature, $10 \mathrm{~g}$ of AT-17 soil was combined 
Table 1 Results of cell cultures on ultrapure agarose, tryptic soy agar, LB agar, and plate count agar plates with water amendments, recording the change in the order of magnitude of CFUs with water amendments (all numbers are scaled by logarithmic transformation and normalized as the difference from the plates without amendments). Positive effects of different volumes of water on microbial growth are in italics, and those caused increase in CFUs more than 1 and 2 orders of magnitude are labeled with ${ }^{+}$and ${ }^{++}$, respectively

\begin{tabular}{|c|c|c|c|c|c|c|c|c|}
\hline Type of culture plate & Amendment & MES & PONR & Yungay & $\mathrm{TZ}-0$ & TZ-4 & TZ-5 & TZ-6 \\
\hline \multirow[t]{3}{*}{ Ultrapure agarose } & $1.5 \mathrm{~mL} \mathrm{H}_{2} \mathrm{O}$ & -1.18 & 0.05 & 0.55 & -0.89 & -0.32 & -1.15 & -1.08 \\
\hline & $3 \mathrm{~mL} \mathrm{H}_{2} \mathrm{O}$ & -1.18 & 0.41 & 0.39 & -0.60 & -0.27 & -0.97 & -0.63 \\
\hline & $4.5 \mathrm{~mL} \mathrm{H}_{2} \mathrm{O}$ & -1.18 & -1.11 & 0.29 & -0.84 & -0.21 & -1.05 & -0.90 \\
\hline \multirow[t]{3}{*}{ Tryptic soy agar } & $1.5 \mathrm{~mL} \mathrm{H}_{2} \mathrm{O}$ & $1.15^{+}$ & 0.42 & -0.58 & -0.24 & -0.17 & -0.36 & -0.16 \\
\hline & $3 \mathrm{~mL} \mathrm{H}_{2} \mathrm{O}$ & 0.05 & -0.19 & $1.57^{+}$ & -0.25 & -0.30 & -0.05 & 0.13 \\
\hline & $4.5 \mathrm{~mL} \mathrm{H}_{2} \mathrm{O}$ & $2.20^{++}$ & $1.80^{+}$ & $1.83^{+}$ & -0.22 & $1.01^{+}$ & -0.41 & 0.20 \\
\hline \multirow[t]{3}{*}{ LB agar } & $1.5 \mathrm{~mL} \mathrm{H}_{2} \mathrm{O}$ & 0.63 & 0.29 & -0.41 & 0.19 & -1.47 & -0.21 & 0.49 \\
\hline & $3 \mathrm{~mL} \mathrm{H}_{2} \mathrm{O}$ & 0.34 & 0.53 & $2.36^{++}$ & 0.42 & -0.95 & 0.22 & 0.32 \\
\hline & $4.5 \mathrm{~mL} \mathrm{H}_{2} \mathrm{O}$ & -0.36 & $2.46^{++}$ & $2.06^{++}$ & 0.73 & 0.71 & -0.40 & 0.45 \\
\hline \multirow[t]{3}{*}{ Plate count agar } & $1.5 \mathrm{~mL} \mathrm{H}_{2} \mathrm{O}$ & 0.65 & $1.65^{+}$ & 0.02 & -0.65 & -0.33 & 0.51 & 0.71 \\
\hline & $3 \mathrm{~mL} \mathrm{H}_{2} \mathrm{O}$ & $1.10^{+}$ & 0.13 & 0.75 & -0.76 & -0.41 & 0.16 & -0.32 \\
\hline & $4.5 \mathrm{~mL} \mathrm{H}_{2} \mathrm{O}$ & 0.91 & $2.65^{++}$ & 0.94 & -0.34 & 0.29 & 0.84 & 0.52 \\
\hline
\end{tabular}

with the salt solution for 4 days at $21{ }^{\circ} \mathrm{C}$ [41]. Duplicate salt-amended soils were suspended in an appropriate volume of sterile ultrapure water and spread on ultrapure agarose, tryptic soy agar, LB agar, and plate count agar plates. Plates were sealed with Bemis ${ }^{\mathrm{TM}}$ Parafilm $^{\mathrm{TM}} \mathrm{M}$ Laboratory Wrapping Film and incubated for 20 days at $21{ }^{\circ} \mathrm{C}$ prior to cell counting [42]. Colony-forming units (CFUs) were determined by the multiplication of the number of colonies, dilution factor, and 1.45 to account for the addition of $4.5 \mathrm{~mL}$ solution to $10 \mathrm{~g}$ soil.

In addition, $1.5 \mathrm{~mL}, 3 \mathrm{~mL}$, and $4.5 \mathrm{~mL}$ of sterile ultrapure water were added to each $10 \mathrm{~g}$ of AT-17 microbiological samples, which covers about the $1 / 3,2 / 3$, and full of soil area, respectively. Since the bottom diameter of Petri dishes used for culturing experiments is $90 \mathrm{~mm}$, these volumes of water are equivalent to approximately $0.24,0.47$, and $0.71 \mathrm{~mm}$ precipitation, respectively. CFUs were cultured and determined in the same manner as salt amendments. CFUs from cultivation experiments were converted via common logarithmic transformation. CFUs on salt amendments were standardized by subtracting their respective $4.5-\mathrm{mL}$ water amendment groups; and CFUs on water amendments were standardized by subtracting their corresponding groups without any amendments.

\section{Data analyses}

Illumina sequence reads of AT-17 bacterial sequencing results were processed with the open-source program Quantitative Insights into Microbial Ecology 2 (QIIME 2). Reads were combined and demultiplexed into Casava 1.8 paired-end format. Reads of low quality were denoised with the DADA2 pipeline plugin of QIIME 2. Reads were filtered by trimming the first 13 base pairs and removing those of low quality, with ambiguous characters and missing barcoded primers, of a length less than 300 base pairs. AT-17 sequences were then clustered into operational taxonomic units (OTUs) at a $99 \%$ similarity cutoff using VSEARCH de novo clustering. The quality of total clustered sequences was double confirmed via noise and chimera pattern checking by VSEARCH and UCHIME. The representative taxonomic identities were aligned at $99 \%$ full-length sequence homology using a pretrained naïve Bayesian classifier [43] based on the SILVA 132 marker gene reference database. All mitochondrial and chloroplast reads were removed using the taxonomy-based filtering of tables and sequences method.

OTU tables were rarefied to remove sampling depth heterogeneity at 23,384 even sampling depth. Alpha diversity indices (binary logarithmic Shannon diversity, Faith's phylogenetic diversity, Pielou's Evenness, and observed OTUs) were computed with the alpha-phylogenetic package of QIIME 2. Alpha rarefaction curves were generated at the maximum 20,000 sequencing depth. Characteristic bacterial phyla associated with the sampling year and aridity were predicted and clustered with the q2-sample-classifier package showing the 100 most representative sequences. Analysis of the composition of microbiomes (ANCOM) was employed to determine the genera that were significantly different among sampling year and aridity. Hierarchical clustering of each individual site using the Bray-Curtis distance matrix was performed in Past 4.03.

Enzyme prediction and functional annotation of constructed sequences were performed in software Phylogenetic 
Investigation of Communities by Reconstruction of Unobserved States 2 (PICRUSt2) based on marker gene sequences. Representative OTUs with nearest-sequenced taxon index (NSTI) more than 2 were excluded from the output. The abundance of predicted functional pathways was standardized as the percentage of the sum of read depths. MetaCyc pathway identifiers were linked to their respective functions at the secondary superclass level using the MetaCyc pathway hierarchy system.

\section{Results}

\section{Soil geochemical features}

To investigate the Atacama soil physicochemical context, samples were analyzed by total organic $\mathrm{C}$ and $\mathrm{N}$ (TOC and TON) quantifications, X-ray diffraction (XRD), X-ray fluorescence (XRF), and ion chromatography (IC). AT-17 sites were generally characterized by quartz $(44 \pm 6 \%)$, albite $(25$ $\pm 6 \%$ ), and microcline $(16 \pm 4 \%)$. However, hydrated minerals, brushite and gypsum, took over a significant percentage (65 $\pm 4 \%$ and $11 \pm 3 \%$ respectively) in the two post-rainfall hyperarid sites-PONR and Yungay (Fig. 1c and Figure S1). The AT-17 soluble salts (i.e., chloride, nitrate, and sulfate) varied significantly between samples: chloride concentrations ranged from 5.8 parts per million (ppm) in TZ-0 to $3600 \mathrm{ppm}$ in TZ-4; nitrate ranged from $1.9 \mathrm{ppm}$ in TZ-0 to $5000 \mathrm{ppm}$ in TZ-4; and sulfate ranged from $24 \mathrm{ppm}$ in TZ-0 to $17,000 \mathrm{ppm}$ in PONR (Table S2). Total soluble salts remained at about the same level within PONR and Yungay and within MES, TZ-5, and TZ-6 (Fig. 1b).

\section{Bacterial abundance and viability}

To assess the abundance and viability of bacterial communities, trypan blue staining assay and cell culture experiments were employed. The viability hereafter was quantified by the ratios of viable cells to total cell counts. Trypan blue stainingdetermined viable and total cell counts of hyperarid sites PONR and Yungay were lower than the southern transition sites (Fig. 2a and Table S3). However, no significant difference in the viable and total cell counts was noted between the northernmost hyperarid site MES and southern transition sites. The active culturable colonies on different types of culture plates increased appreciably toward the transition zone with higher annual precipitation (Fig. 2b, c, d, e). In general, TZ-5 had lower microbial abundance than TZ-4 and TZ-6. The viable:non-viable ratios in AT-17 soils varied from 0.7 in TZ-5 to 8.0 in MES (Table S3), and these ratios were generally higher in the dryer sites than the more humid sites.

Within the hyperarid core of the Atacama Desert in 2017 , TOC was negatively correlated with the contents of sediment sodium $\left(\mathrm{Na}_{2} \mathrm{O}\right)$ and chloride $(\mathrm{Cl})$ (Fig. 3a and b). However,
TOC was positively associated with the concentrations of the water-soluble chloride $(\mathrm{Cl})$ and sulfate $\left(\mathrm{SO}_{4}\right)$ (Fig. 3c and d).

Soil microbial communities showed different preferences to the water volume on different agar plates. Water amendment cultures $(1.5,3$, and $4.5 \mathrm{~mL})$ demonstrated that transition sites were slightly less water limited than hyperarid sites because increasing water content did not change CFUs (Table 1 and Table S4). In general, an increase in water content from 0 to $4.5 \mathrm{~mL}$ increased bacterial cell counts, but the growth rates did not always increase with further water addition. No CFU decrease in the water amendments was more than 1.5 orders of magnitude (Table 1). Overall, excessive sodium chloride and sodium carbonate amendments decreased cell counts; sodium sulfate and sodium acetate had no effect; and sodium L-lactate increased cell counts (Table 2 and Table S4). Sites with higher annual precipitation generally had a higher tolerance or higher preference to the amendments with these salts, except for sodium carbonate (Table 2).

\section{Microbial community diversity and pathway analysis}

To investigate the impact of aridity on Atacama microbial communities, we performed a soil metagenomic analysis of AT-17 bacterial sequence data. The extracted DNA concentrations of all samples were below the limit of detection of Qubit 3.0 dsDNA high-sensitivity assay before amplification. After 29 cycles of PCR, the amplicon concentrations of all samples were exhibited in Table 3. Unfortunately, since the DNA concentrations extracted from PONR and Yungay were not sufficient for sequencing, we could not compare them. For the remaining samples, biodiversity was the lowest in MES, while the highest in TZ-5 and TZ-6 (Table 3 and Figure S2). The diversity was slightly higher in TZ-0 than TZ-4.

In total, 464 bacterial families, 832 genera, and 1112 species were determined. Considering their large quantity, we plotted at the phylum level only (Fig. 4a) and listed the named families with $>2 \%$ proportion in at least one sequenced sample (Table 4). The bacterial phyla dominated soils within the AT-17 hyperarid MES were Actinobacteria $(66.27 \pm 3.94 \%)$, Proteobacteria $(12.65 \pm 2.31 \%)$, and Chloroflexi (11.83 \pm $0.79 \%$ ); and those dominated soils within AT-17 arid southern desert were similarly Actinobacteria (50.42 $\pm 11.84 \%)$, Chloroflexi (16.14 $\pm 8.27 \%$ ), and Proteobacteria (11.47 \pm 2.92\%) (Fig. 4a).

ANCOM results suggested that genus Streptomyces (Actinobacteria) was significantly different $(W=703, p<$ 0.05 ) between the hyperarid core and transition zone. Characteristic known genera in the hyperarid core were Thermus (Deinococcus-Thermus), Escherichia-Shigella (Gammaproteobacteria), and Pseudomonas (Gammaproteobacteria), while characteristic known genera in the transition zone were Rubrobacter (Actinobacteria), 


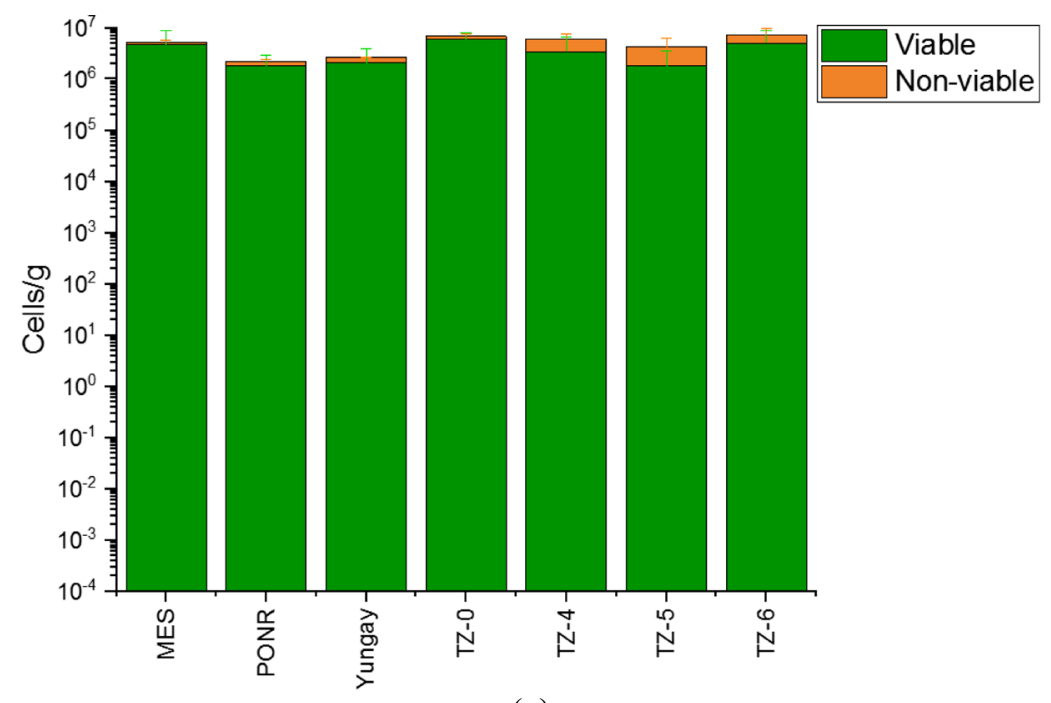

(a)

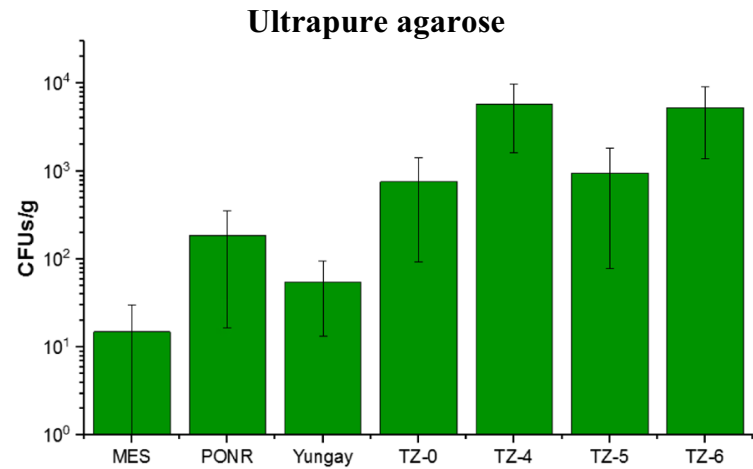

(b)

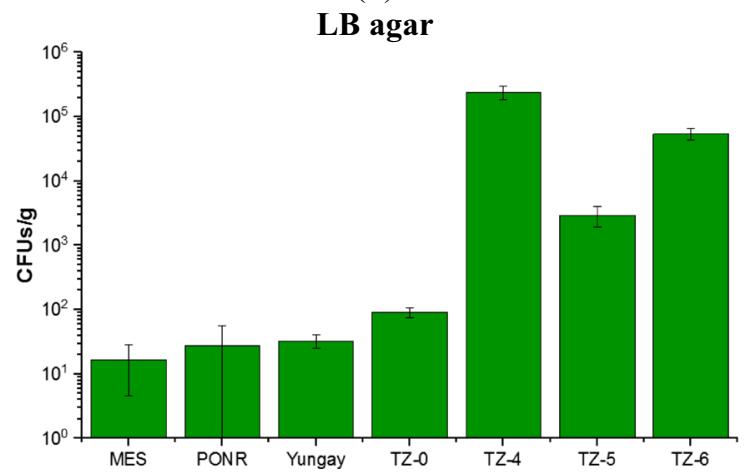

(d)

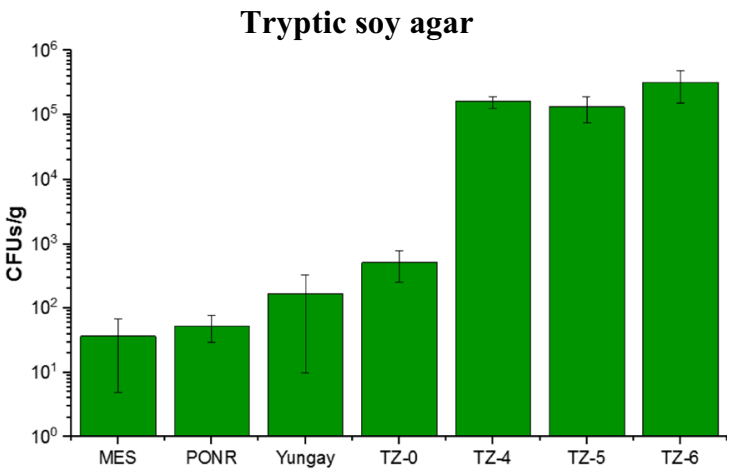

(c)

Plate count agar

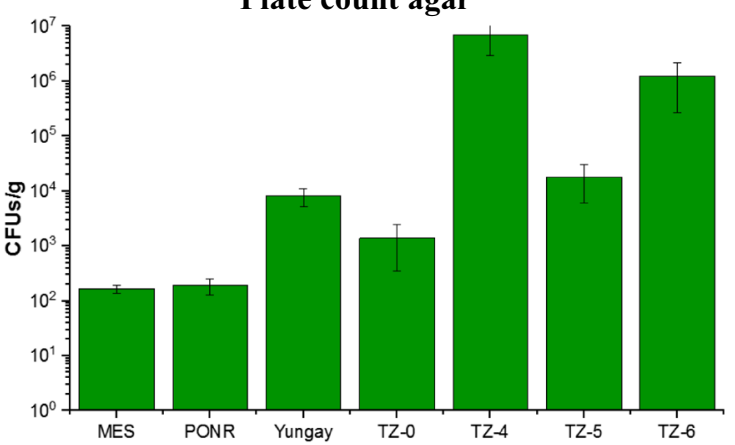

(e)

Fig. 2 a Cumulative bacterial cell counts per gram of soils of AT-17 samples determined by trypan blue staining assay analyses and viable aerobic heterotrophic colony-forming units (CFUs) on $\mathbf{b}$ ultrapure agarose, $\mathbf{c}$ tryptic soy agar, $\mathbf{d}$ LB agar, and e plate count agar plates

uncultured Gammaproteobacteria, Bacillus (Firmicutes), and Solirubrobacter (Actinobacteria).

Hierarchical clustering of species indicated that the three pits within each individual AT-17 site generally had 40\%$75 \%$ similarity (Fig. 4c). The hyperarid microbiome in MES was most similar to the most northern transition site TZ-0, which is in agreement with the statistical classification based on soil fundamental physicochemical parameters [41].

Prior to the marker gene pathway inference, 17 out of 4250 OTUs with NSTI more than 2 were excluded. By Nucleotide
BLAST searching, these 17 excluded OTUs were all uncultured bacterium clones when $E$ value $<10^{-50}$ and percent identity $>80 \% ; 4$ of them also closely related to some Candidatus phylum groups, i.e., Parcubacteria, Nomurabacteria, Uhrbacteria, and Adlerbacteria, respectively. Because of the microbiomic similarity, the metagenome function of MES microbiomes was comparable to the southern transition sites (Fig. 4b). However, the hyperarid site MES had fewer proportions of amine and polyamine biosynthesis, aminoacyl-tRNA charging, detoxification, glycan 


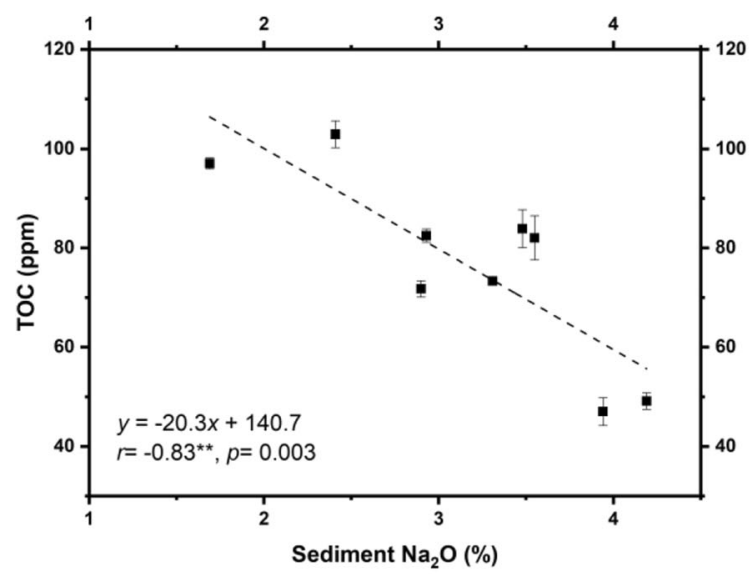

(a)

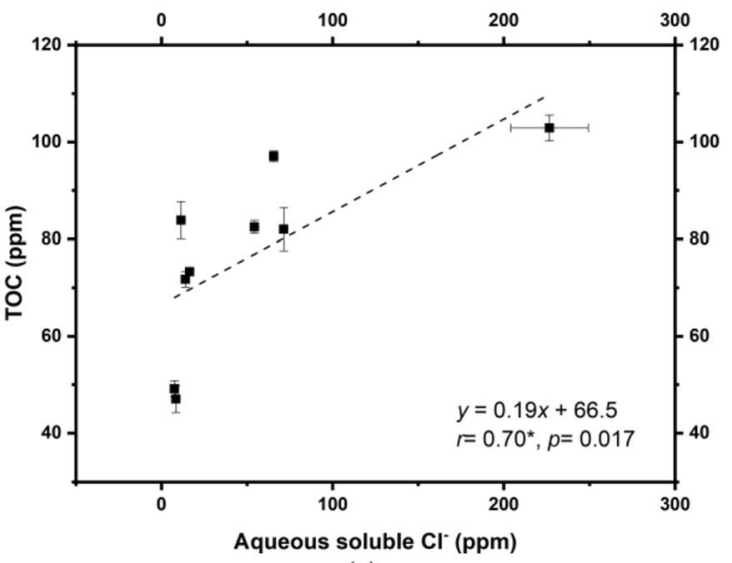

(c)

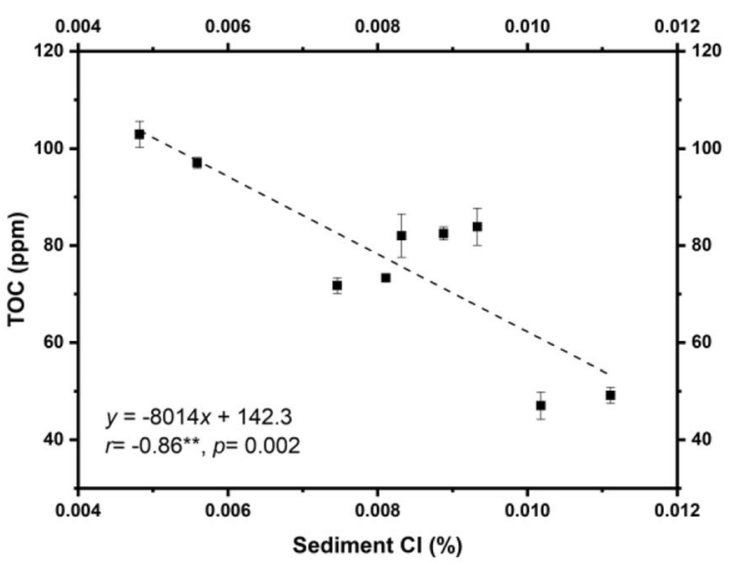

(b)

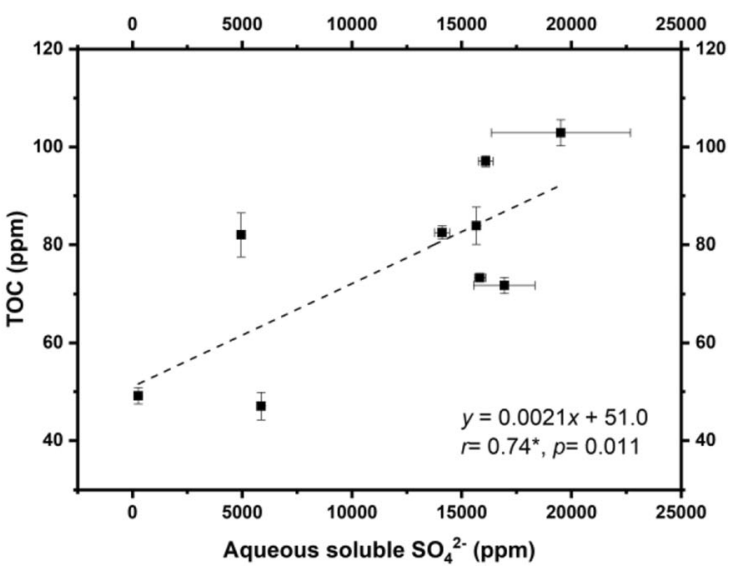

(d)

Fig. 3 Plots of total organic carbon (TOC) and a sediment sodium, b sediment chloride, $\mathbf{c}$ water-soluble chloride, and $\mathbf{d}$ water-soluble sulfate in hyperarid sites

biosynthesis and degradation, nucleoside and nucleotide degradation, polymeric compound degradation, and secondary metabolite degradation.

Various adaptation pathways coupled with environmental stress reactions (including regulations of desiccation, irradiation, salinity, and osmotic pressure) and salt/small organic consumptions were predicted based on feature sequences (Figure S3). Compared to the more southern transition sites, MES and TZ-0 had slightly lower proportions of pathways coupled with stress reactions but higher proportions of nitrate and sulfate utilization pathways (Table 5).

\section{Discussion}

\section{Effects of water and salt regulations on microbial growth}

In the Atacama Desert, atmospherically derived nitrate and other oxyanion salts accumulate in the soil [44], leading to variable soil conductivity, high oxidation potential, and abiotic chemical decomposition of soil organic matter. Our results indicated that while precipitation was a constraint for microbiomes, other geochemical properties also affected the microbial community structure, especially salt availability. As the aridity increased toward the northern hyperarid desert, soluble compounds accumulated at the surface and shallow subsurface. On the other hand, increased precipitation in the southern transition zone restricted these accruals as more salts were delivered deeper, but it also simultaneously enhanced soil salt availability [41, 44].

We found that the viable and total cell counts were remarkably lower in PONR and Yungay, the two hyperarid sites that received massive rainfall before sampling, than the other sites (Fig. 2a and Table S3). However, microbial viability in Atacama soils was variable, with the lowest in the southern desert sites TZ-4 to TZ-6, which was opposite to a previous study before the recent rainfall events [45]. This increased viability in the hyperarid region could be a consequence of the loss of non-viable cells as an additional implication of the rainfall discharge effects $[46,47]$. Across the AT-17 sampling transect, the percentage of viable microbial cells decreased from $\leq 89 \%$ in northern hyperarid soils to $39 \%$ in southern transitional soils (Table S3), similar to other extreme 
Table 2 Results of cell cultures on ultrapure agarose, tryptic soy agar, LB agar, and plate count agar plates with salt amendments, recording the change in the order of magnitude of CFUs with salt amendments (all numbers are scaled by logarithmic transformation and normalized as the difference from the plates with $4.5-\mathrm{mL}$ water amendments). Negative effects of different salts on microbial growth are in italics, and those caused the decrease in CFUs more than 1,2, 3, and 4 orders of magnitude are labeled with ${ }^{-},--,-$, and - , respectively

\begin{tabular}{|c|c|c|c|c|c|c|c|c|}
\hline Type of culture plate & Amendment & MES & PONR & Yungay & TZ-0 & TZ-4 & TZ-5 & TZ-6 \\
\hline \multirow[t]{5}{*}{ Ultrapure agarose } & Chloride & 0 & -0.78 & 0.64 & 0.42 & -0.04 & 1.67 & 0.64 \\
\hline & Sulfate & 0 & $-1.16^{-}$ & -1.64 & -0.62 & -0.35 & 0 & 0.06 \\
\hline & Carbonate & 0 & -0.48 & -0.01 & $-2.05^{-}$ & -0.48 & 0 & 0.72 \\
\hline & Acetate & 0 & -1.16 & 0.37 & 0.64 & -0.94 & 0.90 & 0.35 \\
\hline & L-lactate & 2.34 & 1.87 & 0.67 & 1.00 & $-1.49^{-}$ & 1.63 & 0.18 \\
\hline \multirow[t]{5}{*}{ Tryptic soy agar } & Chloride & $-2.90^{--}$ & $-2.45^{-}$ & 0.50 & -0.24 & $-1.59^{-}$ & 1.22 & 0.01 \\
\hline & Sulfate & $-2.42^{--}$ & $-2.85^{-}$ & 0.05 & 0.58 & -0.77 & 0.82 & 0.01 \\
\hline & Carbonate & $-1.16^{-}$ & $-2.54^{-}$ & 0.38 & $-1.63^{-}$ & $-3.74^{--}$ & 0.02 & -0.14 \\
\hline & Acetate & $-3.38^{---}$ & $-3.15^{--}$ & $-2.09^{--}$ & -0.07 & -0.51 & 0.44 & 0.34 \\
\hline & L-lactate & 0.58 & -1.77 & -0.21 & 0.27 & 0.03 & 0.20 & -0.03 \\
\hline \multirow[t]{5}{*}{ LB agar } & Chloride & -0.86 & $-3.52^{--}$ & $-1.23^{-}$ & -0.56 & $-2.61^{--}$ & -0.08 & -0.11 \\
\hline & Sulfate & 0.48 & $-3.52^{--}$ & $-1.41^{-}$ & 0.24 & $-2.12^{--}$ & 0.40 & 0.38 \\
\hline & Carbonate & 2.57 & $-2.74^{-}$ & $-1.84^{-}$ & $-2.69^{--}$ & $-3.60^{--}$ & 0.22 & -1.54 \\
\hline & Acetate & 0.12 & $-3.22^{--}$ & $-1.18^{-}$ & -0.14 & -0.35 & 0.57 & 0.59 \\
\hline & L-lactate & 1.35 & -1.64 & 0.47 & 0.34 & 0.43 & 0.72 & 0.44 \\
\hline \multirow[t]{5}{*}{ Plate count agar } & Chloride & $-2.75^{--}$ & $-3.21^{--}$ & $-3.38^{--}$ & -0.43 & -0.85 & -0.33 & -0.86 \\
\hline & Sulfate & $-1.16^{-}$ & $-1.99^{-}$ & $-4.84^{--}$ & 1.16 & -0.34 & -0.33 & -0.99 \\
\hline & Carbonate & 0.07 & $-2.69^{--}$ & $-2.60^{--}$ & $-1.08^{-}$ & $-3.49^{--}$ & -0.29 & -1.37 \\
\hline & Acetate & $-2.75^{-}$ & $-3.65^{--}$ & $-2.71^{--}$ & -0.52 & -0.70 & -0.73 & -0.49 \\
\hline & L-lactate & 0.33 & $-2.46^{-}$ & -0.01 & 0.65 & 0.32 & 0.50 & -0.20 \\
\hline
\end{tabular}

environments [48-50] and lower than typical soils usually with more than $90 \%$ viable cells $[51,52]$.

The microbial cultivation experiments (without any amendments) demonstrated that the CFUs from AT-17 samples increased up to 4 orders of magnitude from the hyperarid sites to transition sites (Fig. 2b, c, d, e and Table S4). The reasons for the difference between viable cell counts and culturable microbial colony numbers might be that (1) more unculturable species lived in the hyperarid core $[53,54]$ and that (2) most of the hyperarid microbiomes were metabolically inactive [2, 4, 45, 55]. Since the Actinobacteria-dominated microbial community structure did not alter much between the hyperarid AT-17 and transition AT-17 sites (Fig. 4a), the latter hypothesis might play a more important role in the culturable CFUs. The agar-cultured bacteria from surface samples collected within the Atacama Desert were limited in diversity, and the majority were members of Actinobacteria and Firmicutes. A small amount of Proteobacteria and Bacteroidetes has also been recovered [2, 42]. More specifically, previously identified culturable bacteria belonged to Geodermatophilaceae, Sphingomonas, Bacillus, Arthrobacter, Brevibacillus, Kocuria, Cellulomonas, Hymenobacter, Asticcacaulis, Mesorhizobium, Bradyrhizobium, Afipia, Alphaproteobacteria, and Betaproteobacteria [21, 56]. On our agar plates, these bacterial taxa acted as representatives of the whole microbial community from their sampled sites. Thus, the manner of growth and the change in CFUs of our cultivation experiments primarily reflected the preferences of bacteria within these taxa.

The water amendment experiments suggested that active culturable microorganisms were not impaired by rainfall that was less than $1 \mathrm{~mm}$ per day, as the volumes of water we added to these agar plates. Although the proliferation of some of these microbes manifested a decreasing trend after the abrupt water wash, more microbes benefited from the addition of water (Table 1 and Table S4). However, when precipitation reached as high as the unprecedented rainfall event (19.6 mm) in a few days, massive water input could dissolve soluble salts and concentrated them down to more than 20-cm depth [57, 58]. Amendments with excessive dissolved sodium chloride and sodium carbonate inhibited the growth of active microorganisms on agar plates; amendments with excessive dissolved sodium sulfate and sodium acetate made no difference in microbial growth; only excessive sodium L-lactate amendments promoted the growth of active culturable microbes (Table 2 and Table S4). Unfortunately, since organic C salts were limited in the oxidizing natural environment of the Atacama Desert [2, 59], the dissolved material and the extreme water 
Table 3 Concentrations of triplicate amplicons (means \pm standard errors), Shannon diversity, Faith's phylogenetic diversity (PD), species evenness, and observed OTU richness indices of AT-17 samples

\begin{tabular}{|c|c|c|c|c|c|}
\hline Site & $\begin{array}{l}\text { Amplicon (ng/ } \\
\mu \mathrm{L})\end{array}$ & $\begin{array}{l}\text { Shannon (binary } \\
\log \text { ) }\end{array}$ & $\begin{array}{l}\text { Faith's } \\
\text { PD }\end{array}$ & Evenness & $\begin{array}{l}\text { Observed } \\
\text { OTUs }\end{array}$ \\
\hline AT17-M1 (MES pit 1) & $0.56 \pm 0.05$ & 6.73 & 25.3 & 0.833 & 272 \\
\hline AT17-M2 (MES pit 2) & $0.56 \pm 0.06$ & 5.59 & 16.8 & 0.767 & 156 \\
\hline AT17-M3 (MES pit 3) & $0.47 \pm 0.35$ & 5.60 & 18.9 & 0.772 & 152 \\
\hline $\begin{array}{l}\text { AT17-P1 (PONR pit } \\
\text { 1) }\end{array}$ & $0.05 \pm 0.02$ & - & - & - & - \\
\hline $\begin{array}{l}\text { AT17-P2 (PONR pit } \\
\text { 2) }\end{array}$ & $0.03 \pm 0.03$ & - & - & - & - \\
\hline $\begin{array}{l}\text { AT17-P3 (PONR pit } \\
\text { 3) }\end{array}$ & $0.04 \pm 0.00$ & - & - & - & - \\
\hline $\begin{array}{l}\text { AT17-Y1 (Yungay pit } \\
\text { 1) }\end{array}$ & $0.04 \pm 0.00$ & - & - & - & - \\
\hline $\begin{array}{l}\text { AT17-Y2 (Yungay pit } \\
\text { 2) }\end{array}$ & $<0.01$ & - & - & - & - \\
\hline $\begin{array}{l}\text { AT17-Y3 (Yungay pit } \\
\text { 3) }\end{array}$ & $0.05 \pm 0.05$ & - & - & - & - \\
\hline AT17-T01 (TZ-0 pit 1) & $35.8 \pm 7.7$ & 7.59 & 43.9 & 0.799 & 722 \\
\hline AT17-T02 (TZ-0 pit 2) & $18.6 \pm 3.4$ & 6.99 & 37.6 & 0.767 & 550 \\
\hline AT17-T41 (TZ-4 pit 1) & $10.9 \pm 0.8$ & 7.09 & 38.6 & 0.793 & 494 \\
\hline AT17-T42 (TZ-4 pit 2) & $7.3 \pm 1.3$ & 7.11 & 38.4 & 0.787 & 522 \\
\hline AT17-T43 (TZ-4 pit 3) & $38.3 \pm 8.2$ & 6.72 & 33.1 & 0.788 & 371 \\
\hline AT17-T51 (TZ-5 pit 1) & $35.1 \pm 8.5$ & 8.43 & 50.6 & 0.892 & 699 \\
\hline AT17-T52 (TZ-5 pit 2) & $52.2 \pm 5.0$ & 8.49 & 73.6 & 0.833 & 1172 \\
\hline AT17-T53 (TZ-5 pit 3) & $47.9 \pm 7.2$ & 7.84 & 49.9 & 0.842 & 632 \\
\hline AT17-T61 (TZ-6 pit 1) & $71.7 \pm 8.1$ & 8.32 & 53.0 & 0.859 & 821 \\
\hline AT17-T62 (TZ-6 pit 2) & $42.7 \pm 12.4$ & 8.50 & 52.8 & 0.879 & 813 \\
\hline AT17-T63 (TZ-6 pit 3) & $58.7 \pm 2.5$ & 8.60 & 52.8 & 0.889 & 815 \\
\hline
\end{tabular}

addition might only harm the indigenous microbial communities $[6,10]$, at least in the short term.

In comparison with the results of microbial cultures, the negative correlations between TOC (an approximation of all grain-bound biomass) [21, 41, 60] and sediment sodium/ chloride within the hyperarid core (Fig. 3a and b) were consistent with the negative effects of sodium chloride and some other sodium salts on microbial proliferation (Table 2 and Table S4) [42]. However, TOC content in the hyperarid core was positively associated with water-soluble chloride (Fig. $3 c)$. This inconsistency of the relationships between microbial biomass and chloride in different forms supported our hypotheses that the chloride mineral halite was highly hygroscopic, and the deliquescence process within chloride minerals provided moisture to endolithic microbial communities [61, 62]. The soluble chloride concentration indicated the portion of chloride that deliquesced. The positive correlation between TOC and soluble chloride reflects the beneficial effect of salt deliquescence on microbial biomass but not a direct benefit from chloride ions.

Furthermore, water-soluble sulfate also contributed to microbial biomass as a long-term outcome (Fig. 3d), which disagreed with salt amendment experiments (Table 2 and Table S4). Since sulfate in the Atacama Desert was primarily formed in the hydrated form gypsum (Fig. 1c) [63], more sulfate indicated that larger proportions of gypsum could provide crystallization water to nearby microorganisms [36, 64]. Additionally, some microorganisms could reduce sulfate for energy production and sulfur assimilation (Figure S3 and Table 5) $[65,66]$. Therefore, higher sulfate concentrations could both elevate the moisture in a microhabitat and supply nutrients for microbial life.

\section{Microbial communities and metabolic functions along the latitudinal aridity gradient}

After the heavy rainfall event in June 2017, soluble salts at the shallow subsurface of soils were dissolved and transported to depth. For example, the proportions of brushite and gypsum which contain crystallized water molecules increased remarkably in PONR and Yungay where the recent heavy rainfall had the largest influence (Fig. 1c and Figure S1) compared to minerals before rainfall [67], and chloride minerals became undetectable in all AT-17 sites. Adequate metagenome failed to be extracted from PONR and Yungay soils within the hyperarid area. These two sampling sites had undertaken the most amount of precipitation 6 months before our sampling. Despite more culturable colonies, the trypan blue assay- 
Table 4 Compositions of bacterial families in sampling pits of each Atacama site, displaying the named families that were more than $2 \%$ abundance (percentages in italics) in at least one pit sample

\begin{tabular}{|c|c|c|c|c|c|c|c|c|c|c|c|c|c|c|c|}
\hline Phylum & Family (\%) & M1 & M2 & M3 & $\mathrm{T} 01$ & $\mathrm{~T} 02$ & $\mathrm{~T} 41$ & $\mathrm{~T} 42$ & $\mathrm{~T} 43$ & T51 & T52 & T53 & T61 & T62 & T63 \\
\hline \multirow[t]{7}{*}{ Actinobacteria } & Geodermatophilaceae & 0.6 & 2.1 & 2.0 & 0.2 & 0.1 & 5.6 & 6.5 & 5.6 & 2.4 & 1.0 & 1.4 & 2.4 & 2.6 & 2.2 \\
\hline & Nocardioidaceae & 0.5 & 0.1 & 0.1 & 1.0 & 0.5 & 2.1 & 2.0 & 1.8 & 0.8 & 1.2 & 0.2 & 1.1 & 1.5 & 1.9 \\
\hline & Pseudonocardiaceae & 0.2 & 0.5 & 0.0 & 0.6 & 0.5 & 2.5 & 1.9 & 3.2 & 2.0 & 1.8 & 0.2 & 10.2 & 4.3 & 1.8 \\
\hline & Euzebyaceae & 1.6 & 1.3 & 1.1 & 1.1 & 0.9 & 4.7 & 3.4 & 3.9 & 1.1 & 1.4 & 3.5 & 1.5 & 3.9 & 3.0 \\
\hline & Nitriliruptoraceae & 2.0 & 3.8 & 0.0 & 3.5 & 10.9 & 0.7 & 0.6 & 0.3 & 0.4 & 0.5 & 4.3 & 0.6 & 1.3 & 0.2 \\
\hline & Rubrobacteriaceae & 5.3 & 9.0 & 12.3 & 8.1 & 9.2 & 9.6 & 4.6 & 8.9 & 10.8 & 5.2 & 4.7 & 9.1 & 11.8 & 8.0 \\
\hline & Solirubrobacteraceae & 1.7 & 1.7 & 0.9 & 3.8 & 3.7 & 7.5 & 11.8 & 10.9 & 3.1 & 2.5 & 3.2 & 3.4 & 4.4 & 2.4 \\
\hline Bacteroidetes & Hymenobacteraceae & 0.0 & 0.0 & 0.0 & 0.0 & 0.0 & 3.0 & 3.7 & 2.9 & 0.7 & 0.2 & 0.6 & 0.8 & 0.3 & 0.3 \\
\hline \multirow[t]{4}{*}{ Chloroflexi } & AKIW781 & 3.7 & 6.2 & 2.6 & 3.5 & 1.7 & 9.5 & 13.8 & 10.9 & 3.4 & 3.5 & 1.6 & 5.4 & 5.3 & 2.0 \\
\hline & Kallotenuaceae & 0.0 & 0.0 & 0.0 & 0.0 & 0.0 & 5.6 & 0.8 & 1.8 & 0.0 & 0.0 & 0.0 & 0.2 & 0.2 & 0.1 \\
\hline & Thermobaculaceae & 2.1 & 2.3 & 2.3 & 1.1 & 1.4 & 3.1 & 2.4 & 4.5 & 0.5 & 0.3 & 0.3 & 0.1 & 0.3 & 0.0 \\
\hline & $J G 30-K F-C M 45$ & 0.6 & 0.6 & 0.8 & 1.7 & 1.2 & 7.6 & 6.9 & 8.3 & 0.9 & 1.2 & 1.7 & 1.6 & 2.9 & 2.0 \\
\hline Deinococcus-Thermus & Trueperaceae & 0.3 & 0.0 & 0.0 & 0.0 & 0.0 & 1.2 & 0.9 & 0.9 & 0.2 & 0.1 & 2.2 & 0.0 & 1.0 & 0.1 \\
\hline \multirow[t]{3}{*}{ Firmicutes } & Bacillaceae & 0.0 & 0.0 & 0.4 & 0.0 & 0.0 & 0.2 & 0.2 & 0.2 & 6.8 & 5.3 & 30.8 & 4.4 & 8.6 & 4.5 \\
\hline & Paenibacillaceae & 0.0 & 0.0 & 0.0 & 0.0 & 0.0 & 0.0 & 0.0 & 0.0 & 1.6 & 2.1 & 3.3 & 0.8 & 1.5 & 1.0 \\
\hline & Sporolactobacillaceae & 0.0 & 0.0 & 0.0 & 0.0 & 0.0 & 0.0 & 0.0 & 0.0 & 0.1 & 10.9 & 0.4 & 0.0 & 0.0 & 0.0 \\
\hline Gemmatimonadetes & Longimicrobiaceae & 0.6 & 0.3 & 1.6 & 0.5 & 0.2 & 5.0 & 4.2 & 3.8 & 0.4 & 0.7 & 2.9 & 0.4 & 1.2 & 1.1 \\
\hline Planctomycetes & WD2101 & 0.4 & 0.0 & 0.0 & 3.1 & 1.0 & 0.7 & 0.3 & 0.5 & 2.3 & 2.7 & 1.1 & 1.7 & 1.9 & 2.9 \\
\hline \multirow[t]{3}{*}{ Proteobacteria } & Sphingomonadaceae & 0.6 & 0.5 & 0.2 & 1.5 & 0.8 & 2.5 & 3.8 & 3.3 & 3.5 & 3.0 & 2.0 & 2.1 & 2.5 & 1.3 \\
\hline & Burkholderiaceae & 9.6 & 5.5 & 9.6 & 1.0 & 1.6 & 2.0 & 1.7 & 4.2 & 0.6 & 0.7 & 1.2 & 0.5 & 0.7 & 0.7 \\
\hline & Nitrosococcaceae & 0.0 & 0.0 & 0.0 & 7.0 & 1.8 & 0.0 & 0.0 & 0.0 & 1.7 & 0.6 & 0.1 & 0.4 & 0.2 & 1.1 \\
\hline Verrucomicrobia & Chthoniobacteraceae & 0.0 & 0.0 & 0.0 & 0.4 & 0.2 & 0.0 & 0.0 & 0.0 & 2.5 & 2.5 & 0.3 & 3.0 & 1.9 & 3.9 \\
\hline
\end{tabular}

determined viable and total cell counts of PONR and Yungay were remarkably lower than the other sites, including MES. Additionally, Azua-Bustos et al. (2018) found that excessive rainfall input could significantly diminish microbial communities in the Atacama [6]. Given the water amendment cell culture experiments in this study, water addition probably raises the growth rate of culturable species only. This result also indicated that the extracted metagenomic DNA was contributed more by unculturable extremophilic species.

Although the diversity of unknown phyla could be as high as $40 \%$ [3], the abundance of these species was relatively low (Fig. 4a). Soils of the southern arid desert were generally homogeneous in microbial composition and dominated (> $2 \%$ ) by xerotolerant, halotolerant, and radioresistant Actinobacteria, Chloroflexi, Proteobacteria, Firmicutes, Bacteroidetes, Gemmatimonadetes, Planctomycetes, and Acidobacteria (Fig. 4a), phyla commonly detected in arid desert environments [68]. MES of lower relative humidity than the hyperarid Yungay region [31] possessed 16\% more Actinobacteria percentage than southern arid sites (Fig. 4a). However, compared to Yungay, MES had higher microbial abundance (Fig. 2a), which might result from proper but not overwhelming rainfall input. Given the $40 \%$ similarity between MES and TZ-0 species (Fig. 4c), the structure of microbial communities in the hyperarid region largely shifted toward a pattern that is more common in the southern transition zone (Fig. 4c), to one dominated by Actinobacteria, Proteobacteria, and Chloroflexi (Fig. 4a). This shift indicated the occurrence of a water-driven microbial community perturbation and reorganization in the hyperarid core. As for predicted metabolisms, MES microorganisms had lower proportions of degradation pathways of amines, polyamines, carboxylates, polymeric compounds, and secondary metabolites to save essential organic sources for survival (Fig. 4b).

If the microbial community composition in the pre-rainfall MES was assumed to be similar to the nearby northern hyperarid site KM40 sampled in 2012 [45], these pre-rainfall hyperarid soils were shown to be predominantly composed of Deinococcus-Thermus and Aquificae as previously reported in Shirey (2013), and other characteristic bacterial phyla included Acetothermia, Armatimonadetes, Hydrothermae, and Thermotogae, bacteria within which generally adapted to nutrient-depleted and high-temperature conditions. Actinobacteria that lived in the pre-rainfall hyperarid core of the Atacama Desert before rainfall were extremely low [45]. Besides the long-term hyperaridity, the deficiency of extractable Actinobacteria before rainfall may be also caused by incomplete extraction: some Actinobacteria such as its 


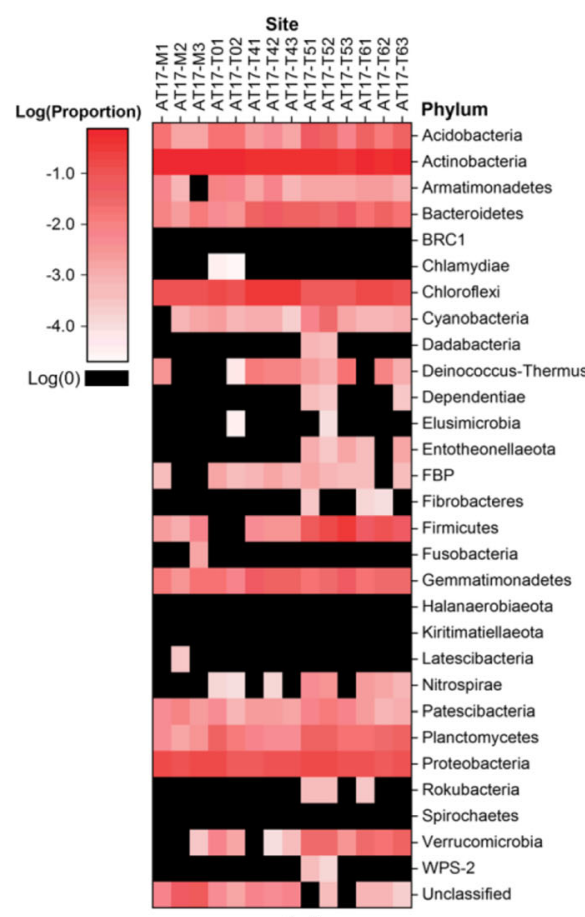

(a)

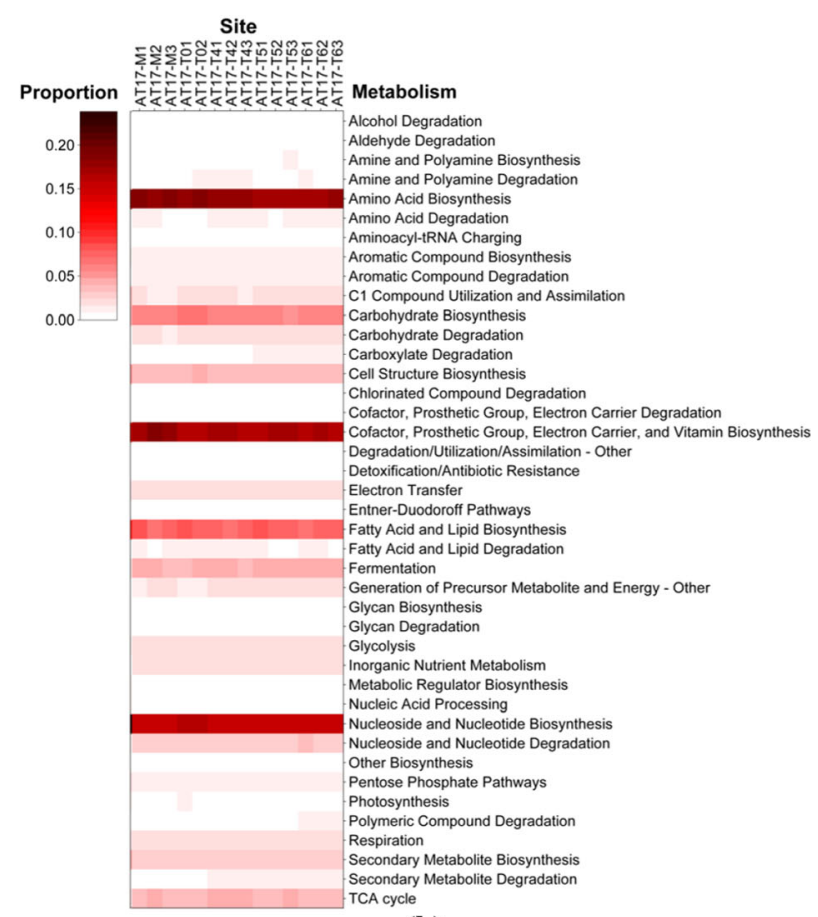

(b)

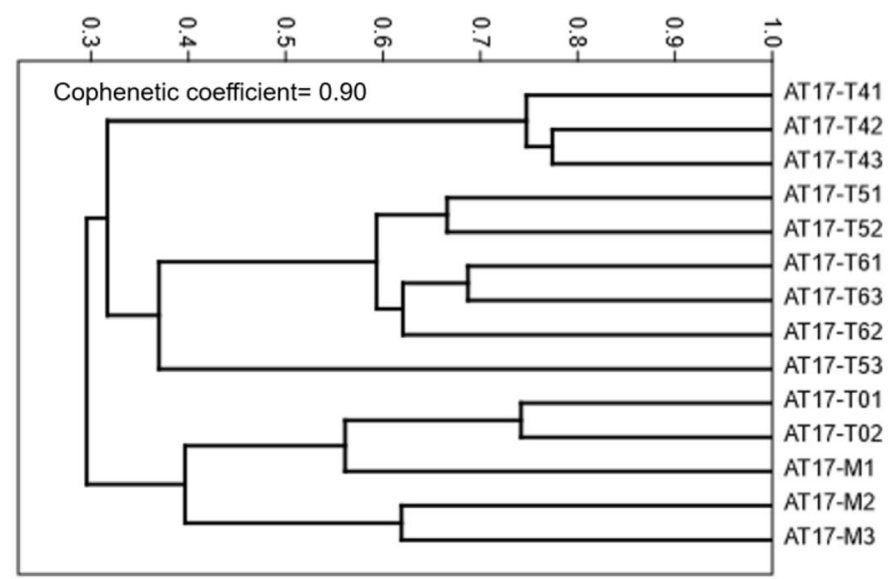

(c)

Fig. 4 a The heatmap illustrating phylum level microbial composition on logarithmic scales in Atacama soils from AT-17 sequencing data. b Relative abundance of predicted microbial metabolisms presented as the secondary superclass in MetaCyc classification system. c Hierarchical clustering (Bray-Curtis distance matrix and unweighted pair group method with arithmetic mean algorithm) of microbial compositions at the species level in AT-17 sites. Abbreviations as in Table 3 thermoalkaliphilic families [69] Geodermatophilaceae, Nocardioidaceae, Pseudonocardiaceae, Rubrobacteriaceae, and Solirubrobacteraceae (Table 4) could form spores that were difficult to break down during DNA extraction to counterattack ultraviolet radiation and dehydration [70]. Analogous to Actinobacteria, the decreased proportions of Firmicutes (Bacillaceae, Paenibacillaceae, and Sporolactobacillaceae) (Table 4) in the hyperarid core after the heavy rainfall might also be a result of their sporulation $[71,72]$. Chthoniobacteraceae of Verrucomicrobia appeared only in the two most humid sampling sites, as they generally metabolize organic carbon from plants [73].

Deinococcus-Thermus bacteria are well-known extremophiles that have previously been detected in calcites, halites, microbialites, and gypsum evaporites of the Atacama Desert. After the heavy rain, within the phylum of Deinococcus-Thermus, dominance shifted from of the order Thermales [45], who were mostly thermoresistant, to a dominance of the order Deinococcales, who were both thermoresistant and radioresistant $[74,75]$. This shift might be triggered by the 
Table 5 Percentages (means \pm standard errors) of predicted metabolic pathways related to stressor responses from Atacama soils in the hyperarid core and the transition zone sampled in 2017

\begin{tabular}{llllll}
\hline Stressor response pathways (\%) & $\begin{array}{l}\text { AT-17 } \\
\text { MES }\end{array}$ & $\begin{array}{l}\text { AT-17 TZ- } \\
0\end{array}$ & $\begin{array}{l}\text { AT-17 TZ- } \\
4\end{array}$ & $\begin{array}{l}\text { AT-17 TZ- } \\
5\end{array}$ & $\begin{array}{l}\text { AT-17 TZ- } \\
6\end{array}$ \\
\hline Desiccation/dehydration & $3.35 \pm 0.18$ & $3.36 \pm 0.09$ & $3.36 \pm 0.03$ & $3.53 \pm 0.16$ & $3.51 \pm 0.03$ \\
Ultraviolet/irradiation & $3.01 \pm 0.15$ & $2.88 \pm 0.28$ & $3.32 \pm 0.07$ & $3.75 \pm 0.11$ & $3.44 \pm 0.01$ \\
Salinity & $1.40 \pm 0.00$ & $1.46 \pm 0.05$ & $1.29 \pm 0.01$ & $1.11 \pm 0.05$ & $1.20 \pm 0.02$ \\
$\begin{array}{l}\text { Simple organic molecule } \\
\quad \text { metabolisms }\end{array}$ & $8.37 \pm 0.11$ & $8.47 \pm 0.30$ & $8.74 \pm 0.17$ & $9.68 \pm 0.15$ & $9.62 \pm 0.25$ \\
Nitrate reduction/assimilation & $2.79 \pm 0.15$ & $2.56 \pm 0.06$ & $2.71 \pm 0.05$ & $2.60 \pm 0.03$ & $2.60 \pm 0.13$ \\
Sulfate reduction/assimilation & $1.25 \pm 0.02$ & $1.26 \pm 0.05$ & $1.13 \pm 0.02$ & $1.11 \pm 0.01$ & $1.12 \pm 0.02$ \\
Osmotic lysis & $7.19 \pm 0.16$ & $7.32 \pm 0.18$ & $7.35 \pm 0.05$ & $7.38 \pm 0.23$ & $7.43 \pm 0.09$ \\
\hline
\end{tabular}

negative facet of water-driven microbial metabolic activation: since water revived dormant microbes, these microbes disarmed sporulation and confronted the harsh ambient conditions, especially ionizing irradiation $[7,8]$. Therefore, the DeinococcusThermus population shifted to a more Deinococcales-dominant structure.

On Mars, the nocturnal availability of a thin layer of liquid water at the subsurface [27, 76-78] can nourish indigenous Martian "microbes" and allow them to slowly thrive with a small amount of moisture daily [7]. The cycle of desiccation and rewetting facilitates dead microbial decomposition, releasing intracellular organics and soil organic matters [8], which also remobilizes nutrients for live microorganisms that are activated from dormancy by liquid water. However, most microorganisms were not culturable (staying dormant or dead) when exposed to brine [6]. Thus, our findings suggested searching for feasibly detectable Martian "life" during the daytime after the evaporation of the nighttime film of liquid brine. Confronting the benefits and challenges brought by the water and salt additions as the aftermath of rewetting, microbial communities in the hyperarid region could likely shift to a structure that is common under more humid conditions in accordance with this study. We therefore infer similar events that may have happened on the wetter early Mars, as well as during the dryingrewetting cycle on the more recent dry Mars.

Supplementary Information The online version contains supplementary material available at https://doi.org/10.1007/s00248-020-01672-w.

Acknowledgments We thank Matthew Holden in the School of Medicine, University of St Andrews, for generously providing the Illumina MiSeq sequencing system. We thank Kerry Pettigrew in the School of Medicine, University of St Andrews, for assisting with Qubit DNA quantitation. We thank Claire Cousins, Lotta Purkamo, and Mark Fox-Powell in the School of Earth and Environmental Sciences, University of St Andrews, for useful discussions upon microbiological analyses.

Availability of Supporting Data The raw sequencing data for microbiome analyses of AT-17 samples in this study are available from the National Center for Biotechnology Information (NCBI) under BioProject ID PRJNA595740.

Funding This research was funded by European Research Council (ERC) under the European Union's Horizon 2020 Research and Innovation Programme (Grant Agreement 678812) (to MWC) for 2017 sampling and various geochemical characterizations, and John Templeton Foundation (Grant Agreement 60501) (to AJW) for assistance with sequencing and bioinformatics. J.S. also acknowledges support from the China Scholarship Council (CSC).

\section{Compliance with Ethical Standards}

Conflict of Interest The authors declare that they have no conflict of interest.

Open Access This article is licensed under a Creative Commons Attribution 4.0 International License, which permits use, sharing, adaptation, distribution and reproduction in any medium or format, as long as you give appropriate credit to the original author(s) and the source, provide a link to the Creative Commons licence, and indicate if changes were made. The images or other third party material in this article are included in the article's Creative Commons licence, unless indicated otherwise in a credit line to the material. If material is not included in the article's Creative Commons licence and your intended use is not permitted by statutory regulation or exceeds the permitted use, you will need to obtain permission directly from the copyright holder. To view a copy of this licence, visit http://creativecommons.org/licenses/by/4.0/.

\section{References}

1. Hartley AJ, Chong G, Houston J, Mather AE (2005) 150 million years of climatic stability: evidence from the Atacama Desert, northern Chile. J Geol Soc Lond 162:421-424. https://doi.org/10. 1144/0016-764904-071

2. Navarro-Gonzalez R, Rainey FA, Molina P, Bagaley DR, Hollen BJ, de la Rosa J, Small AM, Quinn RC, Grunthaner FJ, Caceres L et al (2003) Mars-like soils in the Atacama Desert, Chile, and the dry limit of microbial life. Science 302:1018-1021. https://doi.org/ 10.1126/science. 1089143

3. Contador CA, Veas-Castillo L, Tapia E, Antipan M, Miranda N, Ruiz-Tagle B, Garcia-Araya J, Andrews BA, Marin M, Dorador C et al (2019) Atacama Database: a platform of the microbiome of the 
Atacama Desert. Antonie Van Leeuwenhoek 113:185-195. https:// doi.org/10.1007/s10482-019-01328-x

4. Schulze-Makuch D, Wagner D, Kounaves SP, Mangelsdorf K, Devine KG, de Vera JP, Schmitt-Kopplin P, Grossart HP, Parro V, Kaupenjohann M, Galy A, Schneider B, Airo A, Frösler J, Davila AF, Arens FL, Cáceres L, Cornejo FS, Carrizo D, Dartnell L, DiRuggiero J, Flury M, Ganzert L, Gessner MO, Grathwohl P, Guan L, Heinz J, Hess M, Keppler F, Maus D, McKay CP, Meckenstock RU, Montgomery W, Oberlin EA, Probst AJ, Sáenz JS, Sattler T, Schirmack J, Sephton MA, Schloter M, Uhl J, Valenzuela B, Vestergaard G, Wörmer L, Zamorano P (2018) Transitory microbial habitat in the hyperarid Atacama Desert. Proc Natl Acad Sci USA 115:2670-2675. https://doi.org/10.1073/ pnas. 1714341115

5. Cockell CS, Brown S, Landenmark H, Samuels T, Siddall R, Wadsworth J (2017) Liquid water restricts habitability in extreme deserts. Astrobiology 17:309-318. https://doi.org/10.1089/ast. 2016.1580

6. Azua-Bustos A, Fairen AG, Gonzalez-Silva C, Ascaso C, Carrizo D, Fernandez-Martinez MA, Fernandez-Sampedro M, GarciaDescalzo L, Garcia-Villadangos M, Martin-Redondo MP et al (2018) Unprecedented rains decimate surface microbial communities in the hyperarid core of the Atacama Desert. Sci Rep-Uk 8: 16706. https://doi.org/10.1038/s41598-018-35051-w

7. Stevenson A, Burkhardt J, Cockell CS, Cray JA, Dijksterhuis J, Fox-Powell M, Kee TP, Kminek G, McGenity TJ, Timmis KN, Timson DJ, Voytek MA, Westall F, Yakimov MM, Hallsworth JE (2015) Multiplication of microbes below 0.690 water activity: implications for terrestrial and extraterrestrial life. Environ Microbiol 17:257-277. https://doi.org/10.1111/1462-2920.12598

8. Armstrong A, Valverde A, Ramond JB, Makhalanyane TP, Jansson JK, Hopkins DW, Aspray TJ, Seely M, Trindade MI, Cowan DA (2016) Temporal dynamics of hot desert microbial communities reveal structural and functional responses to water input. Sci RepUk 6:34434. https://doi.org/10.1038/srep34434

9. Uritskiy G, Getsin S, Munn A, Gomez-Silva B, Davila A, Glass B, Taylor J, DiRuggiero J (2019) Halophilic microbial community compositional shift after a rare rainfall in the Atacama Desert. Isme J 13:2737-2749. https://doi.org/10.1038/s41396-019-0468-y

10. Fernandez-Martinez MA, Severino RD, Moreno-Paz M, GallardoCarreno I, Blanco Y, Warren-Rhodes K, Garcia-Villadangos M, Ruiz-Bermejo M, Barberan A, Wettergreen D et al (2019) Prokaryotic community structure and metabolisms in shallow subsurface of Atacama Desert playas and alluvial fans after heavy rains: repairing and preparing for next dry period. Front Microbiol 10:1641. https://doi.org/10.3389/fmicb.2019.01641

11. Fuller ER, Head JW (2002) Amazonis Planitia: the role of geologically recent volcanism and sedimentation in the formation of the smoothest plains on Mars. J Geophys Res Planet 107. https://doi. org/10.1029/2002je001842

12. Grotzinger JP, Gupta S, Malin MC, Rubin DM, Schieber J, Siebach K, Sumner DY, Stack KM, Vasavada AR, Arvidson RE et al (2015) Deposition, exhumation, and paleoclimate of an ancient lake deposit, Gale crater, Mars. Science 350:aac7575. https://doi.org/10.1126/ science.aac7575

13. Di Achille G, Hynek BM (2010) Ancient ocean on Mars supported by global distribution of deltas and valleys. Nat Geosci 3:459-463. https://doi.org/10.1038/Ngeo891

14. Di Achille G, Ori GG, Reiss D (2007) Evidence for late Hesperian lacustrine activity in Shalbatana Vallis, Mars. J Geophys Res Planet 112. https://doi.org/10.1029/2006je002858

15. Irwin RP, Maxwell TA, Howard AD, Craddock RA, Leverington DW (2002) A large paleolake basin at the head of Ma'adim Vallis. Mar Sci 296:2209-2212. https://doi.org/10.1126/science.1071143
16. Ramirez RM, Craddock RA (2018) The geological and climatological case for a warmer and wetter early Mars. Nat Geosci 11:230 237. https://doi.org/10.1038/s41561-018-0093-9

17. Shaheen R, Abramian A, Horn J, Dominguez G, Sullivan R, Thiemens MH (2010) Detection of oxygen isotopic anomaly in terrestrial atmospheric carbonates and its implications to Mars. Proc Natl Acad Sci USA 107:20213-20218. https://doi.org/10. 1073/pnas.1014399107

18. Barros N, Feijoo S, Salgado J, Ramajo B, Garcia JR, Hansen LD (2008) The dry limit of microbial life in the Atacama Desert revealed by calorimetric approaches. Eng Life Sci 8:477-486. https:// doi.org/10.1002/elsc.200820236

19. Crits-Christoph A, Robinson CK, Barnum T, Fricke WF, Davila AF, Jedynak B, McKay CP, DiRuggiero J (2013) Colonization patterns of soil microbial communities in the Atacama Desert. Microbiome 1:28. https://doi.org/10.1186/2049-2618-1-28

20. Lacap DC, Warren-Rhodes KA, McKay CP, Pointing SB (2011) Cyanobacteria and chloroflexi-dominated hypolithic colonization of quartz at the hyper-arid core of the Atacama Desert, Chile. Extremophiles 15:31-38. https://doi.org/10.1007/s00792-0100334-3

21. Lester ED, Satomi M, Ponce A (2007) Microflora of extreme arid Atacama Desert soils. Soil Biol Biochem 39:704-708. https://doi. org/10.1016/j.soilbio.2006.09.020

22. Hecht MH, Kounaves SP, Quinn RC, West SJ, Young SMM, Ming DW, Catling DC, Clark BC, Boynton WV, Hoffman J, DeFlores LP, Gospodinova K, Kapit J, Smith PH (2009) Detection of perchlorate and the soluble chemistry of Martian Soil at the Phoenix Lander Site. Science 325:64-67. https://doi.org/10.1126/science. 1172466

23. Catling DC, Claire MW, Zahnle KJ, Quinn RC, Clark BC, Hecht MH, Kounaves S (2010) Atmospheric origins of perchlorate on Mars and in the Atacama. J Geophys Res Planet 115. https://doi. org $/ 10.1029 / 2009 \mathrm{je} 003425$

24. Stern JC, Sutter B, Freissinet C, Navarro-Gonzalez R, McKay CP, Archer PD, Buch A, Brunner AE, Coll P, Eigenbrode JL et al (2015) Evidence for indigenous nitrogen in sedimentary and aeolian deposits from the Curiosity rover investigations at Gale crater, Mars. Proc Natl Acad Sci USA 112:4245-4250. https://doi.org/10. 1073/pnas.1420932112

25. Makhalanyane TP, Valverde A, Gunnigle E, Frossard A, Ramond JB, Cowan DA (2015) Microbial ecology of hot desert edaphic systems. FEMS Microbiol Rev 39:203-221. https://doi.org/10. 1093/femsre/fuu011

26. Orosei R, Lauro SE, Pettinelli E, Cicchetti A, Coradini M, Cosciotti B, Di Paolo F, Flamini E, Mattei E, Pajola M et al (2018) Radar evidence of subglacial liquid water on Mars. Science 361:490-493. https://doi.org/10.1126/science.aar7268

27. Martinez GM, Renno NO (2013) Water and brines on Mars: current evidence and implications for MSL. Space Sci Rev 175:29-51. https://doi.org/10.1007/s11214-012-9956-3

28. Osterloo MM, Hamilton VE, Bandfield JL, Glotch TD, Baldridge AM, Christensen PR, Tornabene LL, Anderson FS (2008) Chloride-bearing materials in the southern highlands of Mars. Science 319:1651-1654. https://doi.org/10.1126/science.1150690

29. Davila AF, Duport LG, Melchiorri R, Janchen J, Valea S, de Los Rios A, Fairen AG, Mohlmann D, McKay CP, Ascaso C et al (2010) Hygroscopic salts and the potential for life on Mars. Astrobiology 10:617-628. https://doi.org/10.1089/ast.2009.0421

30. Vaniman DT, Martínez GM, Rampe EB, Bristow TF, Blake DF, Yen AS, Ming DW, Rapin W, Meslin PY, Morookian JM (2018) Gypsum, bassanite, and anhydrite at Gale crater, Mars. Am Mineral 103:1011-1020. https://doi.org/10.2138/am-2018-6346

31. Azua-Bustos A, Caro-Lara L, Vicuna R (2015) Discovery and microbial content of the driest site of the hyperarid Atacama Desert, 
Chile. Environ Microbiol Rep 7:388-394. https://doi.org/10.1111/ 1758-2229.12261

32. Crits-Christoph A, Gelsinger DR, Ma B, Wierzchos J, Ravel J, Davila A, Casero MC, DiRuggiero J (2016) Functional interactions of archaea, bacteria and viruses in a hypersaline endolithic community. Environ Microbiol 2064-2077:18-2077. https://doi.org/10. 1111/1462-2920.13259

33. Wierzchos J, Ascaso C, McKay CP (2006) Endolithic cyanobacteria in halite rocks from the hyperarid core of the Atacama Desert. Astrobiology 6:415-422. https://doi.org/10. 1089/ast.2006.6.415

34. Wierzchos J, Camara B, De Los Rios A, Davila AF, Almazo IMS, Artieda O, Wierzchos K, Gomez-Silva B, Mckay C, Ascaso C (2011) Microbial colonization of Ca-sulfate crusts in the hyperarid core of the Atacama Desert: implications for the search for life on Mars. Geobiology 9:44-60. https://doi.org/10.1111/j.1472-4669. 2010.00254.x

35. Wierzchos J, Casero MC, Artieda O, Ascaso C (2018) Endolithic microbial habitats as refuges for life in polyextreme environment of the Atacama Desert. Curr Opin Microbiol 43:124-131. https://doi. org/10.1016/j.mib.2018.01.003

36. Palacio S, Azorin J, Montserrat-Marti G, Ferrio JP (2014) The crystallization water of gypsum rocks is a relevant water source for plants. Nat Commun 5:4660. https://doi.org/10.1038/ ncomms 5660

37. Caceres L, Gomez-Silva B, Garro X, Rodriguez V, Monardes V, Mckay CP (2007) Relative humidity patterns and fog water precipitation in the Atacama Desert and biological implications. J Geophys Res Biogeosci 112. https://doi.org/10.1029/ 2006jg000344

38. de los Rios A, Valea S, Ascaso C, Davila A, Kastovsky J, Mckay CP, Gomez-Silva B, Wierzchos J (2010) Comparative analysis of the microbial communities inhabiting halite evaporites of the Atacama Desert. Int Microbiol 13:79-89. https://doi.org/10.2436/ 20.1501.01.113

39. McKay CP, Friedmann EI, Gomez-Silva B, Caceres-Villanueva L, Andersen DT, Landheim R (2003) Temperature and moisture conditions for life in the extreme arid region of the Atacama Desert: four years of observations including the El Nino of 1997-1998. Astrobiology 3:393-406. https://doi.org/10.1089/ 153110703769016460

40. Brocks JJ, Banfield J (2009) Unravelling ancient microbial history with community proteogenomics and lipid geochemistry. Nat Rev Microbiol 7:601-609. https://doi.org/10.1038/nrmicro2167

41. Shen J, Zerkle AL, Stueken EE, Claire MW (2019) Nitrates as a potential $\mathrm{N}$ supply for microbial ecosystems in a hyperarid Mars analog system. Life 9:79. https://doi.org/10.3390/life9040079

42. Bagaley DR (2006) Uncovering bacterial diversity on and below the surface of a hyper-arid environment, the Atacama Desert. Louisiana State University and Agricultural and Mechanical College, Chile

43. Wang Q, Garrity GM, Tiedje JM, Cole JR (2007) Naive Bayesian classifier for rapid assignment of rRNA sequences into the new bacterial taxonomy. Appl Environ Microbiol 73:5261-5267. https://doi.org/10.1128/AEM.00062-07

44. Ericksen GE (1983) The Chilean nitrate deposits. Am Sci 71:366374

45. Shirey TB (2013) Investigating microbial communities and the environmental factors influencing them in manmade and naturally occurring systems. University of Alabama, Tuscaloosa

46. Pruett CJH, Burges HD, Wyborn CH (1980) Effect of exposure to soil on potency and spore viability of Bacillus-Thuringiensis. $\mathrm{J}$ Invertebr Pathol 35:168-174. https://doi.org/10.1016/00222011(80)90179-2

47. Artz RRE, Townend J, Brown K, Towers W, Killham K (2005) Soil macropores and compaction control the leaching potential of
Escherichia coli O157 : H7. Environ Microbiol 7:241-248. https:// doi.org/10.1111/j.1462-2920.2004.00690.x

48. Hansen AA, Herbert RA, Mikkelsen K, Jensen LL, Kristoffersen T, Tiedje JM, Lomstein BA, Finster KW (2007) Viability, diversity and composition of the bacterial community in a high Arctic permafrost soil from Spitsbergen, Northern Norway. Environ Microbiol 9:2870-2884. https://doi.org/10.1111/j.1462-2920. 2007.01403.x

49. Saul-Tcherkas V, Steinberger Y (2011) Soil microbial diversity in the vicinity of a Negev Desert Shrub-Reaumuria negevensis. Microb Ecol 61:64-81. https://doi.org/10.1007/s00248-010-9763-x

50. Shi T, Reeves RH, Gilichinsky DA, Friedmann EI (1997) Characterization of viable bacteria from Siberian permafrost by 16S rDNA sequencing. Microb Ecol 33:169-179. https://doi.org/ $10.1007 / \mathrm{s} 002489900019$

51. Janssen PH, Yates PS, Grinton BE, Taylor PM, Sait M (2002) Improved culturability of soil bacteria and isolation in pure culture of novel members of the divisions Acidobacteria, Actinobacteria, Proteobacteria, and Verrucomicrobia. Appl Environ Microbiol 68: 2391-2396. https://doi.org/10.1128/Aem.68.5.2391-2396.2002

52. Parinkina $\mathrm{O}$ (1973) Determination of bacterial growth rates in tundra soils. Bull Ecol Res Comm:303-309

53. Ma RP, Xu JY, Wang WB, Yuan W (2009) Seasonal and latitudinal differences of the saturation effect between ionospheric $\mathrm{NmF} 2$ and solar activity indices. J Geophys Res Space 114. https://doi.org/10. 1029/2009ja014353

54. Warren-Rhodes KA, Lee KC, Archer SDJ, Cabrol N, Ng-Boyle L, Wettergreen D, Zacny K, Pointing SB, Chong G, Demargasso C et al (2019) Subsurface microbial habitats in an Extreme Desert Mars-Analog Environment. Front Microbiol 10:69. https://doi.org/ 10.3389/fmicb.2019.00069

55. Zahran HH (1997) Diversity, adaptation and activity of the bacterial flora in saline environments. Biol Fertil Soils 25:211-223. https:// doi.org/10.1007/s003740050306

56. Gómez-Silva B, Rainey FA, Warren-Rhodes KA, McKay CP, Navarro-González R (2008) Atacama Desert soil microbiology. Microbiology of extreme soils. Springer, Berlin, pp 117-132

57. Davis WL, de Pater I, McKay CP (2010) Rain infiltration and crust formation in the extreme arid zone of the Atacama Desert, Chile. Planet Space Sci 58:616-622. https://doi.org/10.1016/j.pss.2009. 08.011

58. Marion GM, Verburg PSJ, McDonald EV, Arnone JA (2008) Modeling salt movement through a Mojave Desert soil. J Arid Environ 72:1012-1033. https://doi.org/10.1016/j.jaridenv.2007. 12.005

59. Quinn RC, Ehrenfreund P, Grunthaner FJ, Taylor CL, Zent AP (2007) Decomposition of aqueous organic compounds in the Atacama Desert and in Martian soils. J Geophys Res Biogeosci 112. https://doi.org/10.1029/2006jg000312

60. Azua-Bustos A, Gonzalez-Silva C, Arenas-Fajardo C, Vicuna R (2012) Extreme environments as potential drivers of convergent evolution by exaptation: the Atacama Desert Coastal Range case. Front Microbiol 3. https://doi.org/10.3389/fmicb.2012.00426

61. Davila AF, Gomez-Silva B, de los Rios A, Ascaso C, Olivares H, Mckay CP, Wierzchos J (2008) Facilitation of endolithic microbial survival in the hyperarid core of the Atacama Desert by mineral deliquescence. J Geophys Res Biogeosci 113:113. https://doi.org/ 10.1029/2007jg000561

62. Finstad K, Probst AJ, Thomas BC, Andersen GL, Demergasso C, Echeverria A, Amundson RG, Banfield JF (2017) Microbial community structure and the persistence of cyanobacterial populations in salt crusts of the Hyperarid Atacama Desert from GenomeResolved Metagenomics. Front Microbiol 8:1435. https://doi.org/ 10.3389/fmicb.2017.01435

63. Voigt C, Klipsch S, Herwartz D, Chong G, Staubwasser M (2020) The spatial distribution of soluble salts in the surface soil of the 
Atacama Desert and their relationship to hyperaridity. Glob Planet Chang 184:103077. https://doi.org/10.1016/j.gloplacha.2019. 103077

64. Shen J, Smith AC, Claire MW, Zerkle AL (2020) Unraveling biogeochemical phosphorus dynamics in hyperarid Mars-analogue soils using stable oxygen isotopes in phosphate. Geobiology 18: 760-779. https://doi.org/10.1111/gbi.12408

65. Korehi H, Blothe M, Sitnikova MA, Dold B, Schippers A (2013) Metal mobilization by iron- and sulfur-oxidizing bacteria in a multiple extreme mine tailings in the Atacama Desert, Chile. Environ Sci Technol 47:2189-2196. https://doi.org/10.1021/es304056n

66. Stivaletta N, Barbieri R, Cevenini F, López-García P (2011) Physicochemical conditions and microbial diversity associated with the evaporite deposits in the Laguna de la Piedra (Salar de Atacama, Chile). Geomicrobiol J 28:83-95. https://doi.org/10.1080/ 01490451003653102

67. Harris JK, Cousins CR, Claire MW (2016) Spectral identification and quantification of salts in the Atacama Desert. Proc SPIE 10005. https://doi.org/10.1117/12.2241520

68. Maza F, Maldonado J, Vasquez-Dean J, Mandakovic D, Gaete A, Cambiazo V, Gonzalez M (2019) Soil bacterial communities from the Chilean Andean Highlands: taxonomic composition and culturability. Front Bioeng Biotechnol 7:10. https://doi.org/10. 3389/fbioe.2019.00010

69. Shivlata L, Satyanarayana T (2015) Thermophilic and alkaliphilic Actinobacteria: biology and potential applications. Front Microbiol 6:1014. https://doi.org/10.3389/fmicb.2015.01014

70. Idris H, Goodfellow M, Sanderson R, Asenjo JA, Bull AT (2017) Actinobacterial rare biospheres and dark matter revealed in habitats of the Chilean Atacama Desert. Sci Rep-Uk 7:8373. https://doi.org/ 10.1038/s41598-017-08937-4

71. Rose HL, Dewey CA, Ely MS, Willoughby SL, Parsons TM, Cox V, Spencer PM, Weller SA (2011) Comparison of eight methods for the extraction of Bacillus atrophaeus spore DNA from eleven common interferents and a common swab. PLoS One 6:e22668. https://doi.org/10.1371/journal.pone.0022668

72. Shen J (2020) Phospholipid biomarkers in Mars-analogous soils of the Atacama Desert. Int J Astrobiol 19:505-514. https://doi.org/10. 1017/S1473550420000294

73. Kant R, van Passel MW, Palva A, Lucas S, Lapidus A, Glavina del Rio T, Dalin E, Tice H, Bruce D, Goodwin L et al (2011) Genome sequence of Chthoniobacter flavus Ellin428, an aerobic heterotrophic soil bacterium. J Bacteriol 193:2902-2903. https://doi.org/10. 1128/JB.00295-11

74. Omelchenko MV, Wolf YI, Gaidamakova EK, Matrosova VY, Vasilenko A, Zhai M, Daly MJ, Koonin EV, Makarova KS (2005) Comparative genomics of Thermus thermophilus and Deinococcus radiodurans: divergent routes of adaptation to thermophily and radiation resistance. BMC Evol Biol 5:57. https://doi.org/10.1186/1471-2148-5-57

75. Battista JR, Earl AM, Park MJ (1999) Why is Deinococcus radiodurans so resistant to ionizing radiation? Trends Microbiol 7:362-365. https://doi.org/10.1016/S0966-842x(99)01566-8

76. Altheide T, Chevrier V, Nicholson C, Denson J (2009) Experimental investigation of the stability and evaporation of sulfate and chloride brines on Mars. Earth Planet Sci Lett 282:69-78. https://doi.org/10.1016/j.eps1.2009.03.002

77. Chevrier V, Hanley J, Altheide T (2009) Stability of perchlorate hydrates and their liquid solutions at the Phoenix landing site, Mars (vol 36, art no L10202, 2009). Geophys Res Lett:36. https://doi.org/ $10.1029 / 2009 \mathrm{gl} 040523$

78. Meslin PY, Gasnault O, Forni O, Schroder S, Cousin A, Berger G, Clegg SM, Lasue J, Maurice S, Sautter V, le Mouelic S, Wiens RC, Fabre C, Goetz W, Bish D, Mangold N, Ehlmann B, Lanza N, Harri AM, Anderson R, Rampe E, McConnochie TH, Pinet P, Blaney D, Leveille R, Archer D, Barraclough B, Bender S, Blake D, Blank JG,
Bridges N, Clark BC, DeFlores L, Delapp D, Dromart G, Dyar MD, Fisk M, Gondet B, Grotzinger J, Herkenhoff K, Johnson J, Lacour JL, Langevin Y, Leshin L, Lewin E, Madsen MB, Melikechi N, Mezzacappa A, Mischna MA, Moores JE, Newsom H, Ollila A, Perez R, Renno N, Sirven JB, Tokar R, de la Torre M, d'Uston L, Vaniman D, Yingst A, MSL Science Team, Kemppinen O, Minitti M, Cremers D, Bell JF, Edgar L, Farmer J, Godber A, Wadhwa M, Wellington D, McEwan I, Newman C, Richardson M, Charpentier A, Peret L, King P, Weigle G, Schmidt M, Li S, Milliken R, Robertson K, Sun V, Baker M, Edwards C, Farley K, Griffes J, Miller H, Newcombe M, Pilorget C, Rice M, Siebach K, Stack K, Stolper E, Brunet C, Hipkin V, Marchand G, Sanchez PS, Favot L, Cody G, Steele A, Fluckiger L, Lees D, Nefian A, Martin M, Gailhanou M, Westall F, Israel G, Agard C, Baroukh J, Donny C, Gaboriaud A, Guillemot P, Lafaille V, Lorigny E, Paillet A, Perez R, Saccoccio M, Yana C, Armiens-Aparicio C, Rodriguez JC, Blazquez IC, Gomez FG, Gomez-Elvira J, Hettrich S, Malvitte AL, Jimenez MM, Martinez-Frias J, Martin-Soler J, MartinTorres FJ, Jurado AM, Mora-Sotomayor L, Caro GM, Lopez SN, Peinado-Gonzalez V, Pla-Garcia J, Manfredi JAR, RomeralPlanello JJ, Fuentes SAS, Martinez ES, Redondo JT, UrquiO'Callaghan R, Mier MPZ, Chipera S, Mauchien P, Manning H, Fairen A, Hayes A, Joseph J, Squyres S, Sullivan R, Thomas P, Dupont A, Lundberg A, DeMarines J, Grinspoon D, Reitz G, Prats B, Atlaskin E, Genzer M, Haukka H, Kahanpaa H, Kauhanen J, Kemppinen O, Paton M, Polkko J, Schmidt W, Siili T, Wray J, Wilhelm MB, Poitrasson F, Patel K, Gorevan S, Indyk S, Paulsen G, Gupta S, Schieber J, Geffroy C, Baratoux D, Cros A, Lee QM, Pallier E, Parot Y, Toplis M, Brunner W, Heydari E, Achilles C, Oehler D, Sutter B, Cabane M, Coscia D, Israel G, Szopa C, Robert F, Nachon M, Buch A, Stalport F, Coll P, Francois P, Raulin F, Teinturier S, Cameron J, Dingler R, Jackson RS, Johnstone S, Little C, Nelson T, Williams RB, Jones A, Kirkland L, Treiman A, Baker B, Cantor B, Caplinger M, Davis S, Duston B, Edgett K, Fay D, Hardgrove C, Harker D, Herrera P, Jensen E, Kennedy MR, Krezoski G, Krysak D, Lipkaman L, Malin M, McCartney E, McNair S, Nixon B, Posiolova L, Ravine M, Salamon A, Saper L, Stoiber K, Supulver K, van Beek J, van Beek T, Zimdar R, French KL, Iagnemma K, Miller K, Summons R, Goesmann F, Hviid S, Johnson M, Lefavor M, Lyness E, Breves E, Fassett C, Bristow T, DesMarais D, Edwards L, Haberle R, Hoehler T, Hollingsworth J, Kahre M, Keely L, McKay C, Wilhelm MB, Bleacher L, Brinckerhoff W, Choi D, Conrad P, Dworkin JP, Eigenbrode J, Floyd M, Freissinet C, Garvin J, Glavin D, Harpold D, Jones A, Mahaffy P, Martin DK, McAdam A, Pavlov A, Raaen E, Smith MD, Stern J, Tan F, Trainer M, Meyer M, Posner A, Voytek M, Anderson RC, Aubrey A, Beegle LW, Behar A, Brinza D, Calef F, Christensen L, Crisp JA, Feldman J, Feldman S, Flesch G, Hurowitz J, Jun I, Keymeulen D, Maki J, Morookian JM, Parker T, Pavri B, Schoppers M, Sengstacken A, Simmonds JJ, Spanovich N, Vasavada AR, Webster CR, Yen A, Cucinotta F, Jones JH, Ming D, Morris RV, Niles P, Nolan T, Radziemski L, Berman D, Dobrea EN, Williams RME, Lewis K, Cleghorn T, Huntress W, Manhes G, Hudgins J, Olson T, Stewart N, Sarrazin P, Grant J, Vicenzi E, Wilson SA, Bullock M, Ehresmann B, Hamilton V, Hassler D, Peterson J, Rafkin S, Zeitlin C, Fedosov F, Golovin D, Karpushkina N, Kozyrev A, Litvak M, Malakhov A, Mitrofanov I, Mokrousov M, Nikiforov S, Prokhorov V, Sanin A, Tretyakov V, Varenikov A, Vostrukhin A, Kuzmin R, Wolff M, McLennan S, Botta O, Drake D, Bean K, Lemmon M, Schwenzer SP, Lee EM, Sucharski R, Hernandez MAP, Avalos JJB, Ramos M, Kim MH, Malespin C, Plante I, Muller JP, Navarro-Gonzalez R, Ewing R, Boynton W, Downs R, Fitzgibbon M, Harshman K, Morrison S, Dietrich W, Kortmann O, Palucis M, Sumner DY, Williams A, Lugmair G, Wilson MA, Rubin D, Jakosky B, BalicZunic T, Frydenvang J, Jensen JK, Kinch K, Koefoed A, Stipp 
SLS, Boyd N, Campbell JL, Gellert R, Perrett G, Pradler I, VanBommel S, Jacob S, Owen T, Rowland S, Atlaskin E, Savijarvi H, Boehm E, Bottcher S, Burmeister S, Guo J, Kohler J, Garcia CM, Mueller-Mellin R, Wimmer-Schweingruber R, Bridges JC, Benna M, Franz H, Bower H, Brunner A, Blau H, Boucher T, Carmosino M, Atreya S, Elliott H, Halleaux D, Renno N, Wong M, Pepin R, Elliott B, Spray J, Thompson L, Gordon S, Williams J,
Vasconcelos P, Bentz J, Nealson K, Popa R, Kah LC, Moersch J, Tate C, Day M, Kocurek G, Hallet B, Sletten R, Francis R, McCullough E, Cloutis E, ten Kate IL, Kuzmin R, Arvidson R, Fraeman A, Scholes D, Slavney S, Stein T, Ward J, Berger J (2013) Soil diversity and hydration as observed by ChemCam at Gale Crater. Mar Sci 341:1238670. https://doi.org/10.1126/science. 1238670 